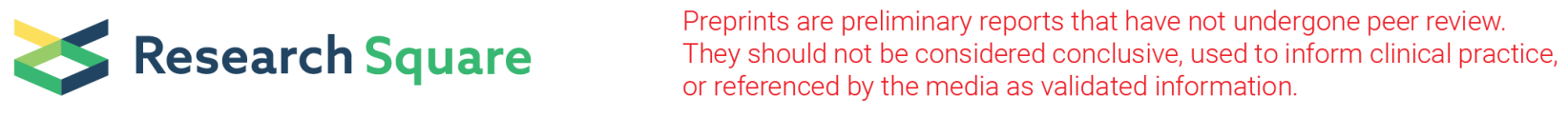

\title{
Determinants of dental caries in children in the Middle East and North Africa region: A systematic review based on literature published from 2000 to 2019
}

Amal Elamin ( $\square$ amal.elamin@zu.ac.ae)

Zayed Univeristy https://orcid.org/0000-0002-4078-2049

Malin Garemo

Zayed University Department of Natural Science and Public Health

Anzelle Mulder

Zayed University Department of Natural Science and Public Health

Research article

Keywords: Children, Dental caries, Eating habits, Middle East, Northern Africa, Oral health, Risk factors, Socioeconomics, Sugar intake, Tooth brushing

Posted Date: January 29th, 2021

DOI: https://doi.org/10.21203/rs.3.rs-154776/v1

License: (c) (i) This work is licensed under a Creative Commons Attribution 4.0 International License. Read Full License 


\section{Abstract \\ Background}

Dental caries risk factors have been expanded to not only emphasize biology and dietary and oral habits but also broader social determinants such as socioeconomic factors and the utilization of health services. The aim was to review sociobehavioural/cultural and socioeconomic determinants of dental caries in children residing in the Middle East and North Africa (MENA) region.

\section{Methods}

A search was conducted in the PubMed/Medline database and Google Scholar to identify studies published from 2000-2019 covering children using key search terms. In the initial stages, titles, abstracts and, if needed, full articles were screened for eligibility. In the final stage, all included articles were reassessed and read, and relevant data were extracted.

\section{Results}

Out of 600 initial articles, a total of 77 were included in this review, of which 74 were cross-sectional, 2 were longitudinal and one was a case-control study. The studies included a total of 94,491 participants in 14 countries across the MENA region. A majority used the World Health Organization scoring system to assess dental caries. The caries prevalence ranged between $17.2-88.8 \%$, early childhood caries between $3-57 \%$ and decayed missing filled teeth (dmft) varied between $0.6-8.5$ across the various age groups. Increased age, low maternal education, low overall socioeconomic status, decreased frequency of tooth brushing, low parental involvement, poor oral habits, infant feeding practices and sugar were among the most prevalent determinants for increased risk of caries in the reviewed studies.

\section{Conclusions}

Dental caries was found to be high among children in many of the studies published from MENA. The key determinants of dental caries were found to include factors related to child characteristics, family background, oral hygiene and infant feeding and eating habits. The high dental caries prevalence emphasises the need to address the prevailing modifiable sociobehavioural and socioeconomic determinants by translating them into effective oral health prevention policies and programmes.

\section{Background}

Dental caries continues to be one of the most prevalent chronic diseases worldwide and a costly burden to healthcare services despite the availability of effective basic prevention measures [1]. Since the declaration of the Millennium Development Goals (MDGs) in 2000 and later the Sustainable Development Goals (SDGs), both of which allowed for tracking countries' health profiles, the profile of the Middle East and North Africa (MENA) region has undergone notable changes [2]. In some MENA countries, political stability, economic growth and investments in healthcare systems have led to improvements in various health indicators, whereas some countries have been impacted by political unrest or war; subsequently, the region currently includes low-middle income, uppermiddle income and high income countries [3,4]. These societal changes have also contributed to an increased rate of non-communicable diseases and persistence of some communicable diseases, such as dental caries, due to a marked shift in lifestyle, increased food availability and a notable nutritional transition among citizens [4].

Globally, the profile of dental caries is also heterogeneous across developing and developed countries, with large disparities reported between and within groups $[5,6]$. Principally, it has been claimed that dental caries is decreasing in most industrialized countries due to improvements in prevention programmes and increased access to dental health services, but conflicting results have shown that dental caries is still prevalent among underprivileged groups in many of these countries $[5,7,8]$. In most developing countries, dental caries levels were low until recent years, after which an increase has been observed due to growing consumption of sugars, inadequate exposure to fluorides and less access to oral healthcare services [5, 8, 9]. In the MENA region, trends in dental caries have shown a rapid increase in the incidence of the disease, with most caries remaining untreated [10]. Existing data from the Eastern Mediterranean Region (EMRO) from 20 countries show wide variations in dental caries with decayed, missing, and filled teeth scores (DMFT) among 12-year-olds ranging from 0.4-4.4 and a higher prevalence and severity of dental caries in the primary dentition than in the permanent dentition among 6-year-olds [10]. Furthermore, distinctions between dental caries experiences are present, with high rates of untreated caries in developing countries, which reflects the limited resources available and difficulties in accessibility and affordability to essential oral health care services [10, 11].

While determinants that contribute to the initiation and progression of dental caries are complex and multifactorial, understanding their role is crucial for establishing appropriate prevention and management strategies [12]. The determinants can be divided into biological, contextual/environmental, sociobehavioural/cultural and socioeconomic factors [13, 14]. Examples of biological determinants include host susceptibility and oral flora, and the contextual/environmental determinants include access to and utilization of dental healthcare services, oral health promotion programmes and fluoridation of water [15]. Moreover, examples of sociobehavioural/cultural determinants regarding dental caries include dental hygiene practices, consumption of sugars, lifestyle habits such as alcohol consumption and tobacco use [16]. To the best of our knowledge, there are no recent studies focusing on sociobehavioural/cultural and socioeconomic determinants of dental caries in children residing in the MENA region. Hence, the aim of the review was to address this gap in the literature. 
The central questions for this review, which incorporated literature from 2000 to 2019 published from the MENA region were:

(1) What sociobehavioural and socioeconomic variables have been studied within the context of dental caries prevalence in children, aged $0-20$ years?

(2) What did the reviewed studies reveal about the influence of sociobehavioural and socioeconomic variables on the risk for dental caries in children?

(3) What recommendations can be made for future research?

\section{Methods}

Electronic searches of databases (PubMed and Medline) and a specialized webpage (scholar.google.com) were used to explore determinants or prevalence of early childhood caries (ECC) or dental caries in children and young adults (age 0-20 years) residing in the MENA region. The World Atlas categorization of the MENA region was used, and accordingly, the following countries were included: Algeria, Bahrain, Egypt, Iran, Iraq, Jordan, Kuwait, Lebanon, Libya, Morocco, Oman, Palestine, Qatar, Saudi Arabia, Syria, Tunisia, Turkey, UAE and Yemen. Combinations of the following MeSH terms were used to identify relevant articles: "caries", "children", "determinants", "behaviours", "dietary causes", "dietary habits", "education, factors, income, socio, social determinants and geographic context (each of the individual countries, e.g., Egypt, Middle East and North Africa). An example of the search strategy used to search MEDLINE: ("determinant" [all fields] AND "caries" [all fields] AND "children" [all fields] AND "country name" [all fields]). Table 1 describes the search terms and examples of search strategies.

\section{Screening process}

A comprehensive literature search was performed and updated until June 2020. One author (AM) undertook the literature search in the specified search databases and a specialized webpage after which the two other authors (AE and MG) removed all the duplicates, identifying 600 articles. The titles and abstracts of the 600 articles were read by all authors and screened for relevance. AE and MG applied the inclusion and exclusion criteria, and when in doubt about the eligibility of an article, both independently read the abstract and, if necessary, the full-text article, after which it was discussed and full consensus was reached.

Duplicate references were checked and removed using Endnote bibliographic software [17].

Inclusion and exclusion criteria

After removal of duplicates, 600 articles were identified through all the search strategies. Thereafter, the initial screening process was conducted to include only articles in English published during January 2000-January 2019 within the MENA region. Following this, the titles, abstracts and, when needed, the articles' full text were screened according to their relevance to the scope of this study, the study design, health and medical conditions in the studied population and finally the age group. Articles that were not relevant to sociocultural, sociobehavioural and socioeconomic determinants of dental caries, such as those examining microbiological and genetic predictors of dental caries, were outside the scope of this study and were therefore excluded. Original crosssectional studies, case-control studies and longitudinal studies were included, whereas reviews, interventional studies, case reports and editorial commentaries were excluded. Furthermore, studies focusing on children/young adults with certain health and medical conditions (cardiovascular disease, autism, diabetes, Down syndrome, etc.) were excluded. The final inclusion criterion that was applied was age, where articles reporting results from children, teenagers and young adults aged 0-20 years were included, whereas findings related to adults were excluded. A few relevant articles where the full-text articles were not accessible were also excluded. This resulted in 77 articles being included for this study, and 523 articles were excluded as described in Figure 1.

\section{Results}

Overall, 77 articles were included in this review from 14 countries: Egypt $(n=4)$ [18-21], Iran $(n=18)$ [22-39], Iraq $(n=2)$ [40, 41], Jordan ( $n=4)$ [42-45], Kuwait $(n=$ 3) [46-48], Lebanon $(n=1)$ [49], Libya $(n=2)$ [50, 51], Palestine $(n=2)$ [52, 53], Qatar $(n=2)$ [54, 55], Saudi Arabia $(n=14)$ [56-69], Syria $(n=4)$ [70-73], Turkey $(n=11)$ [74-84], UAE $(n=8)$ [85-92], and Yemen $(n=2)$ [93, 94]. No relevant published studies were found in Algeria, Bahrain, Morocco, Oman or Tunisia. The studies included a total of 94,491 participants between the ages of 12 months and 20 years. All the studies included both sexes, except four studies from Saudi Arabia where only males were included $[59,60,62,64]$. The majority of the studies were cross-sectional studies (74 studies, $96.1 \%)$ but two longitudinal studies [76, 84] and one case-control study [40] were included. Approximately one-quarter of the studies (21/77) were published from 2000-2009, and the remaining 56 articles were published from 2010-2019. The majority of the included studies used the WHO indices (dmft, dmfs, DMFT, DMFS and their variations) as the scoring system. Other dental caries scoring systems, such as the American Association Paediatric Dentistry (AAPD), the Association of State and Territorial Dental Directors (ASTDD), the British Association for the Study of Community Dentistry (BASCD) and the International Caries Detection and Assessment System (ICADS), were also used for the assessment of ECC and dental caries.

Tables 2-5 show statistically significant determinants/risk factors contributing to dental caries derived from 76 studies. One article from Yemen, which assessed 90 children aged 5-15 years, found a dental caries prevalence of $40.7 \%$ and $75.0 \%$ in girls and boys, respectively. Since no significant associations with $\mathrm{BMI}$, the investigated determinant, were found, the study is not presented in the tables [94]. Potential determinants that were investigated in the 76 studies that were found to be non-statistically significant by the authors of each of the articles were also not included in the tables. Moreover, for each study, the significant determinants/risk factors that had the highest level of statistical analysis are reported in the tables, i.e., if the author/s conducted either a univariate or bivariate analysis as the highest level of analysis, determinants that were found statistically significant for that analysis are reported in the tables. Finally, if the authors conducted a multivariate analysis as the highest level of analysis, only determinants that were found statistically significant in these analyses are reported in the tables, i.e., if determinants were statistically significant in uni- or bivariate analyses did not remain significant in a multivariate analysis, they are not included in the tables. 


\subsection{Determinants related to child characteristics}

Table 2 describes the statistically significant determinants contributing to dental caries that were related to children's sex, age and weight status. Increased age was associated with a higher risk of caries in 18 studies across eight countries (Table 2). Nine studies reported a higher risk of dental caries in males [18$21,27,35,36,47,85]$, while females were reported to have a higher caries risk in six studies $[26,30,31,50,55,65]$. Weight status was significantly associated with caries in nine studies, of which four studies reported positive associations between high BMI/overweight and caries [25, 30, 55, 56] and two studies reported an inverse association between $\mathrm{BMI}$ and dental caries $[47,59]$. Two studies showed a positive association between low BMI/weight and caries [68, 79], and one study reported that normal weight children had a lower caries prevalence than either over- or underweight children [64].

\subsection{Determinants related to family background characteristics}

Table 3 describes the statistically significant determinants related to family background, such as socioeconomic, sociodemographic, geographical location, school type (private or public), and parents' education level, as potential risk factors contributing to dental caries. A total of 17 studies found negative associations with maternal education (13 studies), paternal education (2 studies), or education of both parents combined (2 studies) (Table 3 ).

Parents' employment status was found to be either positively or negatively associated with caries in seven studies $[21,22,32,37,38,62,80]$. Although there was no coherent measurement of socioeconomic status between the reviewed studies, overall socioeconomic status (SES), income, affluence or access to dental insurance were found to have a negative association with dental caries in seven studies, whereas Bener et al. found a positive association between household income and dental caries in Qatar [55]. In addition, significant associations were found between family size, order and numbers of siblings, rural or urban residency, nationality and school type in various studies (Table 3).

\subsection{Determinants related to oral hygiene}

In the reviewed studies, oral hygiene and oral practices were measured directly using plaque or oral hygiene indices or indirectly using self-reports by parents/guardians or participants. Table 4 illustrates statistically significant oral hygiene-related determinants contributing to dental caries. In 11 studies, an association between the frequency of tooth brushing and dental experience was found with reduced dental caries prevalence among those who frequently brushed their teeth and vice versa. Some studies reported an association between parental-related factors such as supervision of tooth brushing (mainly in primary dentition), parental knowledge about oral hygiene, or parental caries status and the caries experience in their children (Table 4).

\subsection{Determinants related to infant feeding and eating habits}

Table 5 presents the statistically significant determinants/risk factors related to infant feeding and eating habits contributing to dental caries. Infant feeding practices such as breastfeeding, bottle feeding and mixed feeding were all positively associated with dental caries in different studies. Furthermore, four studies found a positive association between night feeding and caries $[18,19,34,83]$. Other factors, such as bottle feeding on demand, sleeping with the bottle, sleeping next to the mother, using a (sweetened) dummy, or sharing a spoon with the mother, were also positively associated with caries (Table 5).

The consumption of sweet beverages such as soft drinks (3 studies), fruit juices (3 studies), fruit squashes (3 studies), tea with sugar (2 studies), flavoured milk ( 1 study) and sweet beverages in general ( 2 studies) was positively associated with caries (Table 5). Sugar-containing foods such as cakes, muffins, chocolates, sweets and similar foods were also positively associated with caries in six studies $[20,43,67,72,88,89]$. Higher frequency and/or sweet food snacking/eating was positively associated with caries in six studies [49,60,86, 87, 91, 92], whereas one Lebanese study found that drinking milk as a snack was inversely associated with caries [49]. Other factors, such as cod liver intake, frequent consumption of nutritious food and no fruit consumption, were found to be negatively associated with caries, whereas sweet taste perception, low intake of nutrient-dense food and low dairy product consumption were positively associated with dental caries (Table 5).

\section{Discussion}

The purpose of this review study was to identify, gather, assess and summarize evidence from scientific studies to address sociobehavioural/cultural and socioeconomic determinants of dental caries among children residing in the MENA region. A structured approach was used to identify 77 relevant studies from 14 countries (Egypt, Iran, Iraq, Jordan, Kuwait, Lebanon, Libya, Palestine, Qatar, Saudi Arabia, Syria, Turkey, UAE, and Yemen), whereas no relevant studies were found from Algeria, Bahrain, Morocco, Oman and Tunisia, highlighting a knowledge gap about children's dental status in these specific countries. This study showed a high caries prevalence in many studies regardless of age group or publication date, indicating a worsening dental health status in the MENA region compared to previous reports [95]. The most commonly reported socioeconomic/demographic and behavioural determinants of dental caries in children reported in this review included low parental education level, low household income, frequent consumption of sugars and/or poor dietary habits and poor oral habits, including tooth brushing, dental visits and parental engagement or knowledge on oral hygiene.

Over half of the reviewed articles originated from Iran (18 studies) [22-39], Saudi Arabia (14 studies) [56-69], Turkey (11 studies) [74-84], and the UAE (8 studies) [85-92], with the vast majority being cross-sectional, presenting a snap shot of the regional prevalence of dental caries rather than the development over time. However, based on the available literature from Iran, Saudi Arabia and Turkey, some dental caries patterns and/or trends could be observed. In 2004 and 2006, the dental caries prevalence among Iranian children below the age of 6 years was reported to be $17.2 \%$ and 3-26\%, respectively [23, 33]. In 2011, Amanlou et al. reported a prevalence of $49.3 \%$, whereas studies published in 2017 or later showed a prevalence of $69.9 \%$ and $87 \%$, respectively, indicating a clear trend towards an increased prevalence of dental caries among young children in Iran over the past 15 years [22, 29, 37]. Similar to a previous review study, an increased prevalence of caries has been shown over the past few decades in Saudi Arabia [96]. In this investigation, the four studies published in 2008-2018 reported the dental caries prevalence to be 49\%-91.3\% in different locations of Saudi Arabia [61, 62, 64, 67]. Likewise, in Turkey, high prevalence was also observed among children below the age of 6 years, where five out of the six studies published in 2003-2011 showed that at least three-quarters of 
the children had dental caries [76, 79-82]. Similar to the findings in Saudi Arabia and Turkey, studies from many other MENA countries also reported a high prevalence of dental caries, indicating a concerning development regarding dental status in the region. Sheiham and Williams reported an increased prevalence of dental caries in many African and Middle Eastern countries, supporting these findings [97].

Increased age was identified as an independent risk factor for dental caries in several studies, probably reflecting the cumulative effect of the disease, which is on par with the literature $[14,98]$. Although females may be expected to exhibit a higher caries rate due to earlier tooth eruption and thus longer exposure to cariogenic processes, variations in the associations between sex and dental caries were found in this study. Female sex was associated with a higher risk in six studies, whereas males were at a higher risk in eight of the studies. Others have attributed sex variations to differences in dietary and oral hygiene behaviours or utilization of oral health care $[99,100]$.

The role of parental variables that are directly associated with children's oral health, including sociodemographic characteristics, oral health behaviours, access to health services and other attributes, is evident in this study. In a recent study, this was validated through a conceptual model [101]. SES is generally measured by indicators of human capital, such as income, education, urban/rural living, and occupational nature, which offer advantages or disadvantages to individuals and families. In line with findings from other regions and despite the differences in measuring SES in the reviewed articles, socioeconomic factors were shown to have a significant impact on dental caries [14]. It was primarily mothers' level of education, but also other factors, such as parental occupation, unemployment, low-skilled occupation, low income, overall SES and school type, that were identified as determinants of caries (Table 2).

Most dietary determinants for caries were related to sugar intake: consumption, amount, frequency or timing of sweet beverages, snacks and/or food. The current findings in establishing sugar intake and SES factors as key determinants of dental caries in the region are consistent with those of studies in several other countries that have demonstrated socioeconomic gradients in sugar consumption and may prompt dietary recommendations in limiting added sugar intake and targeting SES disadvantaged groups in the region [102-104]. Moreover, other determinants were identified, such as a lack of an overall healthy diet or intake of certain nutritious foods, which again emphasizes the importance of promoting healthy eating habits and the need for dietary guidelines.

Regarding infant feeding practices, the findings in this study were inconclusive, indicating that both bottle feeding and breastfeeding were associated with higher caries prevalence in different studies $[21,44,55,60]$. These findings are in contrast with those in a systematic review and meta-analysis that concluded that breastfeeding seems to be protective against dental caries when compared to bottle feeding [105].

Tooth brushing as a determinant for caries was a distinct finding in this study; a reduced dental caries experience could be found among those who frequently brush their teeth and vice versa, and this was more apparent in the young age groups with primary dentition $[20,22,37,40,55,60,66,81,89,91]$. Additional determinants related to tooth brushing included age of brushing initiation, frequency, adult supervision and the presence of visible plaque. These factors are all interrelated factors that could potentially also be linked to SES [106, 107].

In this review, the associations between determinants and dental caries were mainly projected from cross-sectional studies. These methodological choices, i.e., the study design (cross-sectional), sampling procedures (e.g., non-population based, convenience sampling), assessment setting and/or outcome measures may be an expected consequence of the relatively immature research infrastructure, limited resources in some of the MENA countries or may be related to social or political turmoil that some countries have experienced $[41,108]$. Although cross-sectional studies may be a feasible option in such circumstances, they only provide a snapshot of risk factors that are associated with the outcome, but causal pathways cannot be determined since the exposure and outcome are measured simultaneously [109]. On the other hand, case-control and longitudinal studies offer greater scientific evidence through better control of possible methodological biases and data analysis, and over time, these types of studies will be needed to further develop and strengthen the research landscape [108]. The aforementioned imbalance in research output between countries hinders the establishment of a comprehensive dental caries profile of the MENA region. This imposes the need to increase dental caries research output in some countries and to devote more rigorous, unique (not repetitive), up-to-date and representative research from others. These steps can strengthen the ability to comprehensively assess trends and determinants of dental caries in the region, allow for cross-country comparisons and identify regional variations in the future.

The strengths of this study include the systematic approach employed in assessing 600 articles published during a period of 20 years focusing on children and young adults. Furthermore, this study focused mainly on modifiable determinants in a region with a young population, which can guide informed dental public health actions and thereby decrease health inequities. The results in this study were reported without assessing the strength/power of either the study design, sampling procedures or the statistical analysis of the included articles, which can be seen as a limitation. Furthermore, the methodological heterogeneity (study design, age group, exposure, outcome measurements, covariates, statistical analyses) among the studies included in this article may have influenced the interpretation of the results; hence, these findings need to be confirmed or rejected by future studies. However, addressing the broad sociobehavioural/cultural and socioeconomic determinants of dental caries offers an outlook of the determinants in a relatively understudied region.

\section{Conclusions}

To conclude, dental caries prevalence was found to be high among children and young adults residing in many countries in the MENA region during the past 20 years. Despite heterogeneity in the study designs and assessment methods of dental caries, the main determinants of dental caries were found to include age, sex, mother's education, overall socioeconomic status, tooth brushing frequency, parents' oral habits/knowledge and sugar consumption. The high dental caries prevalence imposes the need to address the prevailing modifiable sociobehavioural and socioeconomic determinants by translating them into effective oral health prevention policies and programmes. Moreover, a special emphasis on standardizing regional oral health research would further enhance the knowledge and understanding of a major public health problem in the region.

\section{Abbreviations}


AAPD: American Association Paediatric Dentistry, ASTDD: Association of State and Territorial Dental Directors, BASCD: British Association for the Study of Community Dentistry, dmft/DMFT: decayed, missing, and filled (primary/permanent) teeth scores, EMRO: Eastern Mediterranean Region, ICADS: International Caries Detection and Assessment System, MDGs: Millennium Development Goals, MENA: Middle East and North Africa, SES: socioeconomic status, SDG: Sustainable Development Goals, WHO: World Health Organization

\section{Declarations}

\section{Ethical approvals and consent to participate}

Not applicable

\section{Funding}

This research project (titled NOPLAS: Nutrition, Oral Health, Physical Development, Lifestyle, Anthropometric and Socioeconomic Status of Preschool Children in Abu Dhabi) received funding from the Research Incentive Fund (R16055) at Zayed University, UAE. The funding source had no impact on the execution of the study, neither the interpretation of the results nor the writing of the manuscript.

\section{Competing interest}

The authors of this article declare that they have no competing interests.

\section{Availability of data and materials}

The dataset generated and analysed for the current study is not publicly available, but data are available from the corresponding author on reasonable request.

\section{Consent for publication}

Not applicable

\section{Authors' contribution}

$\mathrm{AE}$ and MG contributed to the design of the study, data collection, screening, data analysis, interpretations of results and writing of the manuscript. AM contributed to the screening and writing of the manuscript. All the authors read and approved the final manuscript.

\section{Acknowledgement}

We would like to thank the Research Incentive Fund at Zayed University for financial support.

\section{References}

1. Sheiham A, Alexander D, Cohen L, Marinho V, Moysés S, Petersen PE, Spencer J, Watt RG, Weyant R.Global oral health inequalities: task groupimplementation and delivery of oral health strategies. Adv Dent Res.2011;23:259-267.

2. Asbu EZ, Masri MD, Kaissi A.Health status and health systems financing in the MENA region: roadmap to universal health coverage. Glob Health Res Policy.2017;2:25-25

3. El Bcheraoui C, Jumaan AO, Collison ML, Daoud F, Mokdad AH.Health in Yemen: losing ground in war time. Global Health.2018;14:42.

4. Farrag NS, Cheskin LJ, Farag MK.A systematic review of childhood obesity in the Middle East and North Africa (MENA) region: Prevalence and risk factors meta-analysis. Adv Pediatr Res.2017;4.

5. Kassebaum NJ, Bernabé E, Dahiya M, Bhandari B, Murray CJ, Marcenes W.Global burden of untreated caries: a systematic review and metaregression. J Dent Res.2015;94:650-658.

6. Edelstein BL.The dental caries pandemic and disparities problem. BMC Oral Health.2006;6 Suppl 1:S2.

7. Petersen PE, Bourgeois D, Ogawa H, Estupinan-Day S, Ndiaye C.The global burden of oral diseases and risks to oral health. Bull World Health Organ.2005;83:661-669.

8. Tinanoff N, Baez RJ, Diaz Guillory C, Donly KJ, Feldens CA, McGrath C, Phantumvanit P, Pitts NB, Seow WK, Sharkov N et al.Early childhood caries epidemiology, aetiology, risk assessment, societal burden, management, education, and policy: Global perspective. Int J Paediatr Dent.2019;29:238-248.

9. Lagerweij MD, van Loveren C.Declining Caries Trends: Are We Satisfied? Current oral health reports.2015;2:212-217.

10. Abid A, Maatouk F, Berrezouga L, Azodo C, Uti O, El-Shamy H, Oginni A.Prevalence and Severity of Oral Diseases in the Africa and Middle East Region. Adv Dent Res.2015;27:10-17.

11. Ogunbodede EO, Kida IA, Madjapa HS, Amedari M, Ehizele A, Mutave R, Sodipo B, Temilola S, Okoye L.Oral Health Inequalities between Rural and Urban Populations of the African and Middle East Region. Adv Dent Res.2015;27:18-25.

12. Fejerskov 0.Changing paradigms in concepts on dental caries: consequences for oral health care. Caries Res.2004;38:182-191.

13. Reisine ST, Psoter W.Socioeconomic status and selected behavioral determinants as risk factors for dental caries. J Dent Educ.2001;65:1009-1016. 
14. Harris R, Nicoll AD, Adair PM, Pine CM.Risk factors for dental caries in young children: a systematic review of the literature. Community Dent Health.2004;21:71-85.

15. Fejerskov O, Kidd E: Dental caries: the disease and its clinical management: John Wiley \& Sons; 2009.

16. Petersen PE.Sociobehavioural risk factors in dental caries - international perspectives. Community Dent Oral Epidemiol.2005;33:274-279.

17. The EndNote Team: EndNote. In., EndNote X9 edn. Philadelphia, PA: Clarivate; 2013.

18. Kabil N, Eltaweil S.Reshuffling the Risk Factors of Severe Early Childhood Caries. Dent J.2016.

19. Kabil NS, Eltawil S.Prioritizing the Risk Factors of Severe Early Childhood Caries. Dent J.2017;5.

20. Abbass MMS, Mahmoud SA, El Moshy S, Rady D, AbuBakr N, Radwan IA, Ahmed A, Abdou A, Al Jawaldeh A.The prevalence of dental caries among Egyptian children and adolescences and its association with age, socioeconomic status, dietary habits and other risk factors. A cross-sectional study. F1000Res.2019;8:8.

21. Abu Hamila N.Early childhood caries and certain risk factors in a sample of children 1-3.5 years in Tanta. Dentistry.2013;4:1-3.

22. Amanlou M, Jafari S, Afzalianmand N, Bahrampour Omrany Z, Farsam H, Nabati F, Bagherzadeh K.Association of saliva fluoride level and socioeconomic factors with dental caries in 3-6 years old children in tehran-iran. Iran J Pharm Res.2011;10:159-166.

23. Askarizadeh N, Siyonat P.The prevalence and pattern of nursing caries in preschool children of Tehran. J Indian Soc Pedod Prev Dent.2004;22:92-95.

24. Babaei A, Pakdaman A, Hessari H, Shamshiri AR.Oral health of 6-7 year-old children according to the Caries Assessment Spectrum and Treatment (CAST) index. BMC Oral Health.2019;19:20.

25. Bagherian A, Sadeghi M.Association between dental caries and age-specific body mass index in preschool children of an Iranian population. Indian $\mathrm{J}$ Dent Res.2013;24:66-70.

26. Bashirian S, Shirahmadi S, Seyedzadeh-Sabounchi S, Soltanian AR, Karimi-Shahanjarini A, Vahdatinia F.Association of caries experience and dental plaque with sociodemographic characteristics in elementary school-aged children: a cross-sectional study. BMC Oral Health.2018;18:7.

27. Bayat-Movahed S, Samadzadeh H, Ziyarati L, Memary N, Khosravi R, Sadr-Eshkevari PS.Oral health of Iranian children in 2004: a national pathfinder survey of dental caries and treatment needs. East Mediterr Health J.2011;17:243-249.

28. Eslamipour F, Borzabadi-Farahani A, Asgari I.The relationship between aging and oral health inequalities assessed by the DMFT index. Eur J Paediatr Dent.2010;11:193-199.

29. Haghdoost AA, Hessari H, Baneshi MR, Rad M, Shahravan A.The impact of mother's literacy on child dental caries: Individual data or aggregate data analysis? J Educ Health Promot.2017;6:5.

30. Jahani Y, Eshraghian MR, Rahimi Foroushani A, Nourijelyani K, Mohammad K, Shahravan A, Alam M.Effect of Family Structure and Behavioral and Eyesight Problems on Caries Severity in Pupils by Using an Ordinal Logistic Model. Iran J Public Health.2013;42:889-895.

31. Khani-Varzegani F, Erfanparast L, Asghari-Jafarabadi M, Shokravi M, Azabdaftari F, Parto M, Shokrvash B.Early occurrence of childhood dental caries among low literate families. BMC Res Notes.2017;10:366.

32. Khodadadi E, Niknahad A, Sistani MM, Motallebnejad M.Parents' Oral Health Literacy and its Impact on their Children's Dental Health Status. Electron Physician.2016;8:3421-3425.

33. Mohebbi SZ, Virtanen JI, Vahid-Golpayegani M, Vehkalahti MM.Early childhood caries and dental plaque among 1-3-year-olds in Tehran, Iran. J Indian Soc Pedod Prev Dent.2006;24:177-181.

34. Mohebbi SZ, Virtanen JI, Vahid-Golpayegani M, Vehkalahti MM.Feeding habits as determinants of early childhood caries in a population where prolonged breastfeeding is the norm. Community Dent Oral Epidemiol.2008;36:363-369.

35. Sadeghi M, Lynch CD, Arsalan A.Is there a correlation between dental caries and body mass index-for-age among adolescents in Iran? Community Dent Health.2011;28:174-177.

36. Saied-Moallemi Z, Virtanen JI, Tehranchi A, Murtomaa H.Disparities in oral health of children in Tehran, Iran. Eur Arch Paediatr Dent.2006;7:262-264.

37. Shaghaghian S, Abolvardi M, Akhlaghian M.Factors Affecting Dental Caries of Preschool Children in Shiraz, 2014. J Dent (Shiraz).2018;19:100-108.

38. Sistani MMN, Hataminia Z, Hajiahmadi M, Khodadadi E.Nine years' trend of dental caries and severe early childhood caries among 3-6-year-old children in Babol, Northern Iran. Electron Physician.2017;9:4683-4688.

39. Yazdani R, Esfahani EN, Kharazifard MJ.Relationship of Oral Health Literacy with Dental Caries and Oral Health Behavior of Children and Their Parents. J Dent (Tehran).2018;15:275-282.

40. Al-Mendalawi MD, Karam NT.Risk factors associated with deciduous tooth decay in Iraqi preschool children. Avicenna J Med.2014;4:5-8.

41. Ahmed NA, Astrom AN, Skaug N, Petersen PE.Dental caries prevalence and risk factors among 12-year old schoolchildren from Baghdad, Iraq: a post-war survey. Int Dent J.2007;57:36-44.

42. Rajab LD, Petersen PE, Baqain Z, Bakaeen G.Oral health status among 6- and 12-year-old Jordanian schoolchildren. Oral Health Prev Dent.2014;12:99107.

43. Sayegh A, Dini EL, Holt RD, Bedi R.Food and drink consumption, sociodemographic factors and dental caries in 4-5-year-old children in Amman, Jordan. Br Dent J.2002;193:37-42.

44. Sayegh A, Dini EL, Holt RD, Bedi R.Caries prevalence and patterns and their relationship to social class, infant feeding and oral hygiene in 4-5-year-old children in Amman, Jordan. Community Dent Health.2002;19:144-151.

45. Sayegh A, Dini EL, Holt RD, Bedi R.Oral health, sociodemographic factors, dietary and oral hygiene practices in Jordanian children. J Dent.2005;33:379388. 
46. Al-Mutawa SA, Shyama M, Al-Duwairi Y, Soparkar P.Dental caries experience of Kuwaiti schoolchildren. Community Dent Health.2006;23:31-36.

47. Goodson JM, Tavares M, Wang X, Niederman R, Cugini M, Hasturk H, Barake R, Alsmadi O, Al-Mutawa S, Ariga J et al.Obesity and dental decay: inference on the role of dietary sugar. PLoS One.2013;8:e74461.

48. Al-Mutawa SA, Shyama M, Al-Duwairi Y, Soparkar P.Dental caries experience of Kuwaiti kindergarten schoolchildren. Community Dent Health.2010;27:213217.

49. Chedid NR, Bourgeois D, Kaloustian H, Baba NZ, Pilipili C.Caries prevalence and caries risk in a sample of Lebanese preschool children. Odontostomatol Trop.2011;34:31-45.

50. Huew R, Waterhouse PJ, Moynihan PJ, Maguire A.Prevalence and severity of dental caries in Libyan schoolchildren. Int Dent J.2011;61:217-223.

51. Huew R, Waterhouse P, Moynihan P, Kometa S, Maguire A.Dental caries and its association with diet and dental erosion in Libyan schoolchildren. Int J Paediatr Dent.2012;22:68-76.

52. Azizi Z.The prevalence of dental caries in primary dentition in 4- to 5-year-old preschool children in northern palestine. Int J Dent.2014;2014:839419.

53. Sgan-Cohen HD, Bajali M, Eskander L, Steinberg D, Zini A.Dental Caries Status, Socio-Economic, Behavioral and Biological Variables among 12-Year-Old Palestinian School Children. J Clin Pediatr Dent.2015;39:331-335.

54. Al-Darwish M, El Ansari W, Bener A.Prevalence of dental caries among 12-14 year old children in Qatar. Saudi Dent J.2014;26:115-125.

55. Bener A, Al Darwish MS, Tewfik I, Hoffmann GF.The impact of dietary and lifestyle factors on the risk of dental caries among young children in Qatar. J Egypt Public Health Assoc.2013;88:67-73.

56. Abu El Qomsan MA, Alasqah MN, Alqahtani FA, Alobaydaa MA, Alharbi MM, Kola Z.Intricate Evaluation of Association between Dental Caries and Obesity among the Children in Al-Kharj City (Saudi Arabia). J Contemp Dent Pract.2017;18:29-33.

57. Al-Malik MI, Holt RD, Bedi R.Erosion, caries and rampant caries in preschool children in Jeddah, Saudi Arabia. Community Dent Oral Epidemiol.2002;30:1623.

58. Al-Meedani LA, Al-Dlaigan YH.Prevalence of dental caries and associated social risk factors among preschool children in Riyadh, Saudi Arabia. Pak J Med Sci.2016;32:452-456.

59. Alghamdi AA, Almahdy A.Association Between Dental Caries and Body Mass Index in Schoolchildren Aged Between 14 and 16 Years in Riyadh, Saudi Arabia. J Clin Med Res.2017;9:981-986.

60. Alhabdan YA, Albeshr AG, Yenugadhati N, Jradi H.Prevalence of dental caries and associated factors among primary school children: a population-based cross-sectional study in Riyadh, Saudi Arabia. Environ Health Prev Med.2018;23:60.

61. AlHumaid J, Salloot Z, Al-Ansari A, El Tantawi M, AlYousef Y, Al-Harbi F.Contribution of preventive methods in controlling caries among Saudi primary schoolchildren: a population-based cross-sectional study. Acta Odontol Scand.2018;76:422-426.

62. Amin TT, Al-Abad BM.Oral hygiene practices, dental knowledge, dietary habits and their relation to caries among male primary school children in Al Hassa, Saudi Arabia. Int J Dent Hyg.2008;6:361-370.

63. Ashi H, Campus G, Berteus Forslund H, Hafiz W, Ahmed N, Lingstrom P.The Influence of Sweet Taste Perception on Dietary Intake in Relation to Dental Caries and BMI in Saudi Arabian Schoolchildren. Int J Dent.2017;2017:4262053.

64. Bhayat A, Ahmad MS, Fadel HT.Association between body mass index, diet and dental caries in Grade 6 boys in Medina, Saudi Arabia. East Mediterr Health J.2016;22:687-693.

65. Farsi DJ, Elkhodary HM.The prevalence of overweight/obesity in high school adolescents in Jeddah and the association of obesity association with dental caries. Ann Saudi Med.2017;37:114-121.

66. Paul TR.Dental health status and caries pattern of preschool children in Al-Kharj, Saudi Arabia. Saudi Med J.2003;24:1347-1351.

67. Quadri FA, Hendriyani H, Pramono A, Jafer M.Knowledge, attitudes and practices of sweet food and beverage consumption and its association with dental caries among schoolchildren in Jazan, Saudi Arabia. East Mediterr Health J.2015;21:403-411.

68. Quadri MF, Hakami BM, Hezam AA, Hakami RY, Saadi FA, Ageeli LM, Alsagoor WH, Faqeeh MA, Dhae MA.Relation between Dental Caries and Body Mass Index-for-age among Schoolchildren of Jazan City, Kingdom of Saudi Arabia. J Contemp Dent Pract.2017;18:277-282.

69. Wyne A, Darwish S, Adenubi J, Battata S, Khan N.The prevalence and pattern of nursing caries in Saudi preschool children. Int J Paediatr Dent.2001;11:361-364.

70. Ballouk MA, Dashash M.Caries prevalence and dental health of 8-12 year-old children in Damascus city in Syria during the Syrian Crisis; a cross-sectional epidemiological oral health survey. BMC Oral Health.2019;19:16.

71. Dashash M, Blinkhorn A.The dental health of 5 year-old children living in Damascus, Syria. Community Dent Health.2012;29:209-213.

72. Jaghasi I, Hatahet W, Dashash M.Dietary patterns and oral health in schoolchildren from Damascus, Syrian Arab Republic. East Mediterr Health J.2012;18:358-364.

73. Qadri G, Nourallah A, Splieth CH.Early childhood caries and feeding practices in kindergarten children. Quintessence Int.2012;43:503-510.

74. Cinar AB, Murtomaa H.Interrelation between obesity, oral health and life-style factors among Turkish school children. Clin Oral Investig.2011;15:177-184.

75. Cinar B, Murtomaa H.Clustering of obesity and dental health with lifestyle factors among Turkish and Finnish pre-adolescents. Obes Facts.2008;1:196202.

76. Cogulu D, Ersin NK, Uzel A, Eronat N, Aksit S.A long-term effect of caries-related factors in initially caries-free children. Int J Paediatr Dent.2008;18:361367. 
77. Doğan D, Dülgergil CT, Mutluay AT, Yıldırım I, Hamidi MM, Colak H.Prevalence of caries among preschool-aged children in a central Anatolian population. J Nat Sci Biol Med.2013;4:325-329.

78. İnan-Eroğlu E, Özşin-Özler C, Erçim RE, Büyüktuncer Z, Uzamış-Tekçiçek M, Güçiz-Doğan B.Is diet quality associated with early childhood caries in preschool children? A descriptive study. Turk J Pediatr.2017;59:537-547.

79. Köksal E, Tekçiçek M, Yalçin SS, Tuğrul B, Yalçin S, Pekcan G.Association between anthropometric measurements and dental caries in Turkish school children. Cent Eur J Public Health.2011;19:147-151.

80. Namal N, Vehit HE, Can G.Risk factors for dental caries in Turkish preschool children. J Indian Soc Pedod Prev Dent.2005;23:115-118.

81. Namal N, Yüceokur AA, Can G.Significant caries index values and related factors in 5-6-year-old children in Istanbul, Turkey. East Mediterr Health J.2009;15:178-184.

82. Olmez S, Uzamis M, Erdem G.Association between early childhood caries and clinical, microbiological, oral hygiene and dietary variables in rural Turkish children. Turk J Pediatr.2003;45:231-236.

83. Ozer S, Sen Tunc E, Bayrak S, Egilmez T.Evaluation of certain risk factors for early childhood caries in Samsun, Turkey. Eur J Paediatr Dent.2011;12:103106.

84. Tulunoğlu O, Ulusu T, Işik EE, Tezkirecioğlu M, Genç Y.The prevalence and surface distribution of caries among schoolchildren in Ankara, Turkey according to their dental health behaviors. J Clin Pediatr Dent.2007;31:240-245.

85. Hashim R, Thomson WM, Ayers KM, Lewsey JD, Awad M.Dental caries experience and use of dental services among preschool children in Ajman, UAE. Int J Paediatr Dent.2006;16:257-262.

86. Hashim R, Williams S, Thomson WM.Severe early childhood caries and behavioural risk indicators among young children in Ajman, United Arab Emirates. Eur Arch Paediatr Dent.2011;12:205-210.

87. Hashim R, Williams S, Thomson WM.Oral hygiene and dental caries in 5- to 6-year-old children in Ajman, United Arab Emirates. Int J Dent Hyg.2013;11:208-215.

88. Hashim R, Williams SM, Murray Thomson W.Diet and caries experience among preschool children in Ajman, United Arab Emirates. Eur J Oral Sci.2009;117:734-740.

89. Elamin A, Garemo M, Gardner A.Dental caries and their association with socioeconomic characteristics, oral hygiene practices and eating habits among preschool children in Abu Dhabi, United Arab Emirates - the NOPLAS project. BMC Oral Health.2018;18:104.

90. Khadri FA, Gopinath VK, Hector MP, Davenport ES.Evaluating the risk factors that link obesity and dental caries in 11-17-year-old school going children in the United Arab Emirates. Eur J Dent.2018;12:217-224.

91. Kowash MB, Alkhabuli JO, Dafaalla SA, Shah A, Khamis AH.Early childhood caries and associated risk factors among preschool children in Ras AlKhaimah, United Arab Emirates. Eur Arch Paediatr Dent.2017;18:97-103.

92. Kowash MB.Severity of early childhood caries in preschool children attending Al-Ain Dental Centre, United Arab Emirates. Eur Arch Paediatr Dent.2015;16:319-324.

93. Al-Otaibi MF, Al-Mamari F, Baskaradoss JK.Oral health status of 12-year-old school children in Yemen. A cross- sectional survey. Eur J Paediatr Dent.2012;13:324-328.

94. Salah N.Comparison of oral health in children aged 5-6 years in the Czech Republic and Yemen. Cent Eur J Public Health.2018;26:305-309.

95. World Health Organization Oral Health Programme: Global data on dental caries prevalence (DMFT) in children aged 12 years / Global Oral Data Bank, Oral Health/Area Profile Programme. In. Geneva: World Health Organization; 2000.

96. Al-Ansari AA.Prevalence, severity, and secular trends of dental caries among various Saudi populations: A literature review. Saudi J Med Med Sci.2014;2:142.

97. Sheiham A, Williams D.Reducing inequalities in oral health in the Africa and Middle East region. Advances in Dental Research.2015;27:4-9.

98. Bernabé E, Sheiham A.Age, period and cohort trends in caries of permanent teeth in four developed countries. Am J Public Health.2014;104:e115-e121.

99. Lukacs JR, Largaespada LL.Explaining sex differences in dental caries prevalence: Saliva, hormones, and "life-history" etiologies. Am J Hum Biol.2006;18:540-555.

100. Martinez-Mier EA, Zandona AF.The impact of gender on caries prevalence and risk assessment. Dental Clinics.2013;57:301-315.

101. Buldur B.Pathways between parental and individual determinants of dental caries and dental visit behaviours among children: Validation of a new conceptual model. Community Dent Oral Epidemiol.2020.

102. Bolt-Evensen K, Vik FN, Stea TH, Klepp KI, Bere E.Consumption of sugar-sweetened beverages and artificially sweetened beverages from childhood to adulthood in relation to socioeconomic status - 15 years follow-up in Norway. Int J Behav Nutr Phys Act.2018;15:8.

103. Darmon N, Drewnowski A.Does social class predict diet quality? Am J Clin Nutr.2008;87:1107-1117.

104. Schwendicke F, Dörfer C, Schlattmann P, Page LF, Thomson W, Paris S.Socioeconomic inequality and caries: a systematic review and meta-analysis. J Dent Res.2015;94:10-18.

105. Avila WM, Pordeus IA, Paiva SM, Martins CC.Breast and Bottle Feeding as Risk Factors for Dental Caries: A Systematic Review and Meta-Analysis. PLoS One.2015;10:e0142922.

106. Peres MA, Peres KG, De Barros AJD, Victora CG. The relation between family socioeconomic trajectories from childhood to adolescence and dental caries and associated oral behaviours. J Epidemiol Community Health.2007;61:141-145. 
107. Polk DE, Weyant RJ, Manz MC.Socioeconomic factors in adolescents' oral health: are they mediated by oral hygiene behaviors or preventive interventions? Community Dent Oral Epidemiol.2010;38:1-9.

108. Behbehani JM, Shah NM.Oral health in Kuwait before the Gulf War. Med Princ Pract.2002;11 Suppl 1:36-43.

109. Levin KA.Study design III: Cross-sectional studies. Evid Based Dent.2006;7:24-25.

\section{Tables}

Table 1. Search terms and examples of search strategies using PubMed, Medline and Google scholar

\begin{tabular}{|c|c|}
\hline $\begin{array}{l}\text { Search } \\
\text { category }\end{array}$ & Search words \\
\hline Children & Children \\
\hline Dental caries & Caries \\
\hline Determinants & Behaviours, Determinants, Dietary causes, Dietary habits, Education, Factors, Income, Socio, Social determinants \\
\hline $\begin{array}{l}\text { Geographic } \\
\text { Context }^{\#}\end{array}$ & $\begin{array}{l}\text { Algeria, Bahrain, Egypt, Iran, Iraq, Jordan, Kuwait, Lebanon, Libya, Morocco, Oman, Palestine, Qatar, Saudi Arabia, Syria, Tunisia, Turkey, } \\
\text { UAE, Yemen, Middle East, North Africa }\end{array}$ \\
\hline \multirow{9}{*}{$\begin{array}{l}\text { Examples of } \\
\text { search } \\
\text { strategies }\end{array}$} & . Determinants AND caries AND children AND Middle East \\
\hline & Factors AND caries AND children AND North Africa \\
\hline & - $\quad$ Behaviours AND caries AND children AND Algeria \\
\hline & - $\quad$ Socio AND caries AND children AND Bahrain \\
\hline & . Dietary causes AND caries AND children AND Egypt. \\
\hline & Dietary habits AND caries AND children AND Iran \\
\hline & Education AND caries AND children AND Iraq \\
\hline & . Income AND caries AND children and Jordan \\
\hline & Social determinants AND caries AND children AND Kuwait \\
\hline
\end{tabular}

\#Countries being part of the Middle East and North Africa (MENA) according to the World Atlas categorization, 2018.

Table 2 Statistically significant determinants related to children's sex, age and weight status contributing to dental caries 


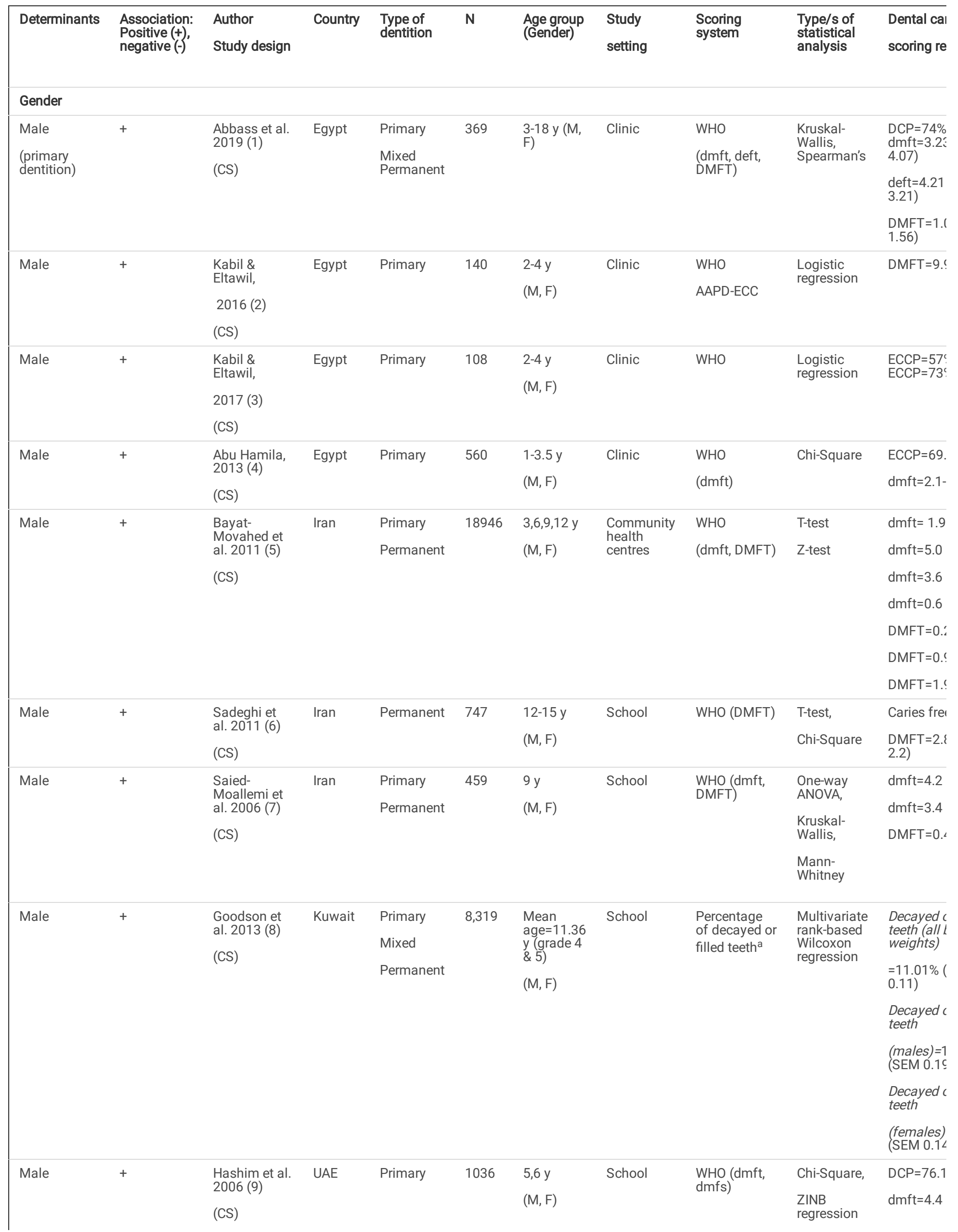




\begin{tabular}{|c|c|c|c|c|c|c|c|c|c|c|}
\hline Female & + & $\begin{array}{l}\text { Bashirian et } \\
\text { al. } 2018 \text { (10) } \\
\text { (CS) }\end{array}$ & Iran & $\begin{array}{l}\text { Primary } \\
\text { Permanent }\end{array}$ & 988 & $\begin{array}{l}7-12 y \\
(M, F)\end{array}$ & School & $\begin{array}{l}\text { WHO } \\
\text { (dmft, DMFT) }\end{array}$ & $\begin{array}{l}\text { Multiple } \\
\text { regression }\end{array}$ & $\begin{array}{l}\mathrm{DCP}=80.3 \\
\mathrm{dmft}=3.67 \\
\text { DMFT }=0 .\end{array}$ \\
\hline Female & + & $\begin{array}{l}\text { Khani- } \\
\text { Varzegani et } \\
\text { al. } 2017 \text { (11) } \\
\text { (CS) }\end{array}$ & Iran & Primary & 756 & $\begin{array}{l}4-7 y \\
(M, F)\end{array}$ & School & $\begin{array}{l}\text { WHO } \\
\text { (dmft) }\end{array}$ & $\begin{array}{l}\text { Multivariate } \\
\text { analysis }\end{array}$ & $\begin{array}{l}\text { dmft med } \\
\text { (25th-75tt } \\
\text { percentile } \\
\text { All=4(2-8) } \\
\text { Males=4( } \\
\text { Females= }\end{array}$ \\
\hline Female & + & $\begin{array}{l}\text { Jahani et al. } \\
2013 \text { (12) } \\
\text { (CS) }\end{array}$ & Iran & $\begin{array}{l}\text { Primary } \\
\text { Permanent }\end{array}$ & 845 & $\begin{array}{l}9 y \\
(M, F)\end{array}$ & School & $\begin{array}{l}\text { WHO (dmft, } \\
\text { DMFT) }\end{array}$ & $\begin{array}{l}\text { Ordinal } \\
\text { logistic } \\
\text { regression }\end{array}$ & $\begin{array}{l}\text { Moderate } \\
\mathrm{DCP}=50^{\mathrm{c}} \\
\text { children }\end{array}$ \\
\hline Female & + & $\begin{array}{l}\text { Farsi } \\
\text { \&Elkhodary } \\
2017 \text { (13) } \\
\text { (CS) }\end{array}$ & KSA & Permanent & 801 & $\begin{array}{l}\text { Mean } \\
\text { age=16.5 } \\
\text { y (Grade } \\
11) \\
(\mathrm{M}, \mathrm{F})\end{array}$ & School & ASTDD (DT) & $\begin{array}{l}\text { Mann- } \\
\text { Whitney }\end{array}$ & $\begin{array}{l}\text { DT boys=: } \\
3.5) \\
\text { DT girls }=\angle \\
3.7)\end{array}$ \\
\hline Female & + & $\begin{array}{l}\text { Huew et al. } \\
2011 \text { (14) } \\
\text { (CS) }\end{array}$ & Libya & Permanent & 791 & $\begin{array}{l}12 \mathrm{y} \\
(\mathrm{M}, \mathrm{F})\end{array}$ & School & $\begin{array}{l}\text { WHO (DMFT, } \\
\text { DMFS) }\end{array}$ & $\begin{array}{l}\text { Multivariate } \\
\text { analysis }\end{array}$ & $\begin{array}{l}\mathrm{DCP}=57.8 \\
\mathrm{DMFT}=1 . \\
\mathrm{DMFS}=2 .\end{array}$ \\
\hline Female & + & $\begin{array}{l}\text { Bener et al. } \\
2013 \text { (15) } \\
\text { (CS) }\end{array}$ & Qatar & Permanent & 1284 & $\begin{array}{l}6-15 y \\
(M, F)\end{array}$ & Clinic & WHO (DMFT) & $\begin{array}{l}\text { Multivariate } \\
\text { analysis }\end{array}$ & $\begin{array}{l}\mathrm{DCP}=73 \% \\
\mathrm{DMFT}=4 . !\end{array}$ \\
\hline Gender & Unclear & $\begin{array}{l}\text { Khadri et al. } \\
2018 \text { (16) } \\
\text { (CS) }\end{array}$ & UAE & Permanent & 803 & $\begin{array}{l}11-17 y \\
(M, F)\end{array}$ & School & WHO (DMFT) & $\begin{array}{l}\text { Multivariate } \\
\text { regression }\end{array}$ & $\begin{array}{l}\text { DCP }=75 \% \\
\text { DMFT }=3 . \\
2.9)\end{array}$ \\
\hline Age & & & & & & & & & & \\
\hline Age & + & $\begin{array}{l}\text { Abbass et al. } \\
2019(1) \\
\text { (CS) }\end{array}$ & Egypt & $\begin{array}{l}\text { Primary. } \\
\text { Mixed, } \\
\text { Permanent }\end{array}$ & 369 & $\begin{array}{l}3-18 \text { y, (M, } \\
F)\end{array}$ & Clinic & $\begin{array}{l}\text { WHO } \\
\text { (dmft, deft, } \\
\text { DMFT) }\end{array}$ & $\begin{array}{l}\text { Kruskal- } \\
\text { Wallis, } \\
\text { Spearman's }\end{array}$ & $\begin{array}{l}\text { DCP }=74 \% \\
\mathrm{dmft}=3.2 \\
4.07) \\
\text { deft= } \\
3.21) \\
\\
\text { DMFT }=1 .(1 \\
1.56)\end{array}$ \\
\hline Age & + & $\begin{array}{l}\text { Abu Hamila, } \\
2013(4) \\
\text { (CS) }\end{array}$ & Egypt & Primary & 560 & $\begin{array}{l}1-3.5 y \\
(M, F)\end{array}$ & Clinic & $\begin{array}{l}\text { WHO } \\
\text { (dmft) }\end{array}$ & Chi-Square & $\begin{array}{l}\mathrm{ECCP}=69 . \\
\mathrm{dmft}=2.1-\end{array}$ \\
\hline Age & + & $\begin{array}{l}\text { Bashirian et } \\
\text { al. } 2018 \text { (10) } \\
\text { (CS) }\end{array}$ & Iran & $\begin{array}{l}\text { Primary } \\
\text { Permanent }\end{array}$ & 988 & $\begin{array}{l}7-12 y \\
(M, F)\end{array}$ & School & $\begin{array}{l}\text { WHO } \\
(\mathrm{dmft}, \mathrm{DMFT})\end{array}$ & $\begin{array}{l}\text { Multiple } \\
\text { regression }\end{array}$ & $\begin{array}{l}\mathrm{DCP}=80.3 \\
\mathrm{dmft}=3.61 \\
\text { DMFT }=0 .\end{array}$ \\
\hline Age & + & $\begin{array}{l}\text { Shaghaghian } \\
\text { et al. } 2018 \\
\text { (17) } \\
\text { (CS) }\end{array}$ & Iran & Primary & 396 & $\begin{array}{l}3-6 y, \\
(M, F)\end{array}$ & School & $\begin{array}{l}\text { WHO } \\
\text { (dmft) }\end{array}$ & $\begin{array}{l}\text { Multivariate } \\
\text { analysis }\end{array}$ & $\begin{array}{l}\mathrm{DCP}=69.9 \\
\mathrm{dmft}=3.8 \varepsilon\end{array}$ \\
\hline Age & + & $\begin{array}{l}\text { Khani- } \\
\text { Varzegani et } \\
\text { al. } 2017 \text { (11) } \\
\text { (CS) }\end{array}$ & Iran & Primary & 756 & $\begin{array}{l}4-7 y \\
(M, F)\end{array}$ & School & $\begin{array}{l}\text { WHO } \\
\text { (dmft) }\end{array}$ & $\begin{array}{l}\text { Multivariate } \\
\text { analysis }\end{array}$ & $\begin{array}{l}\text { Median (2 } \\
\text { 75th perct } \\
\text { dmft: } \\
\text { All=4 (2-8) } \\
\text { Boys }=4(2 \\
\text { Girls=5 (2. }\end{array}$ \\
\hline Age & + & $\begin{array}{l}\text { Eslamipour } \\
\text { et al. } 2010\end{array}$ & Iran & Permanent & 748 & $11-20 y$ & School & WHO (DMFT) & $\begin{array}{l}\text { Chi-Square, } \\
\text { Binary }\end{array}$ & $\mathrm{DCP}=88.8$ \\
\hline
\end{tabular}




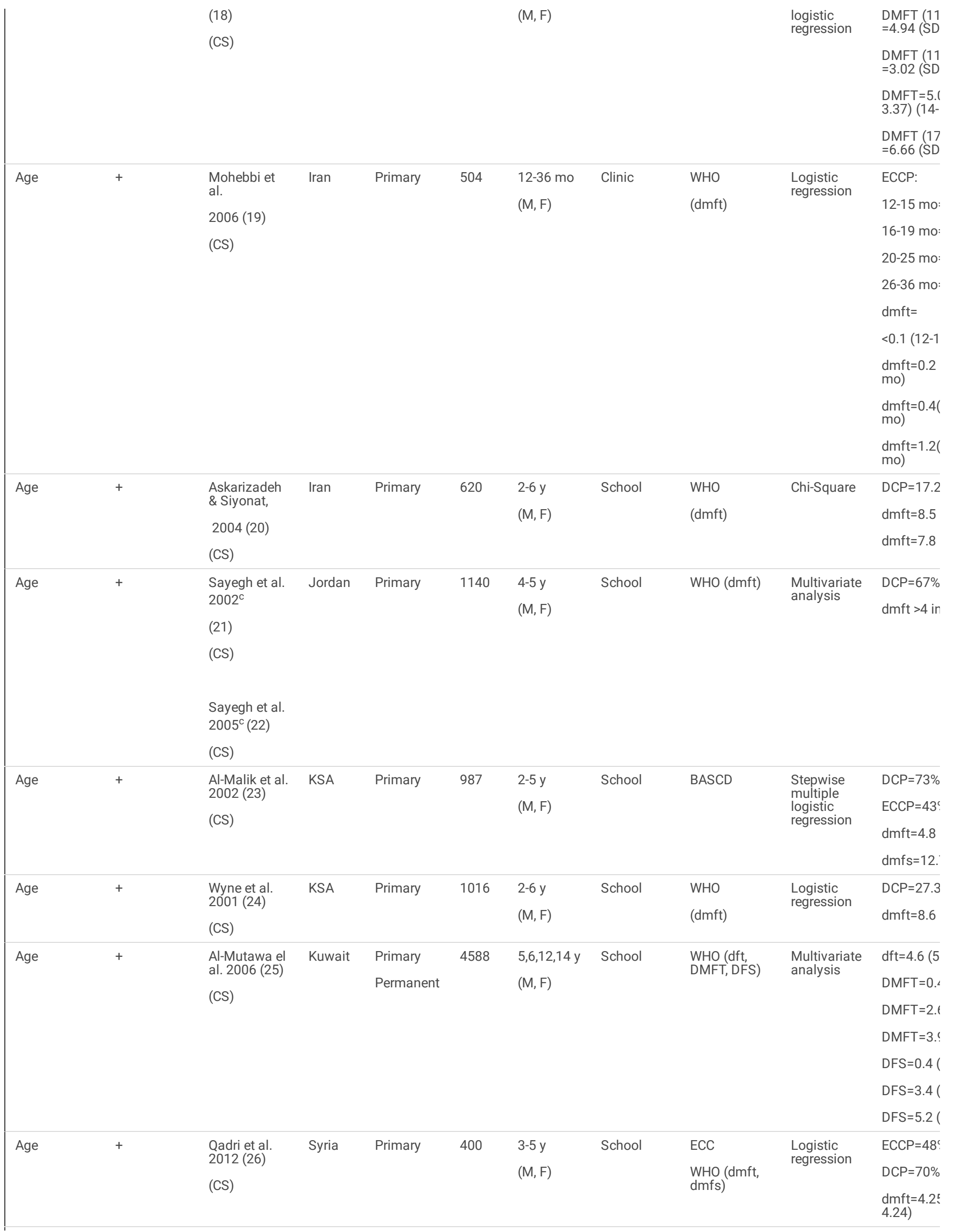




\begin{tabular}{|c|c|c|c|c|c|c|c|c|c|c|}
\hline Age & + & $\begin{array}{l}\text { İnan-Eroğlu } \\
\text { et al. } 2017 \\
\text { (27) } \\
\text { (CS) }\end{array}$ & Turkey & Primary & 395 & $\begin{array}{l}\text { 36-71 mo, } \\
(\mathrm{M}, \mathrm{F})\end{array}$ & School & $\begin{array}{l}\text { WHO } \\
\text { (dmft, dmfs) }\end{array}$ & $\begin{array}{l}\text { Mann- } \\
\text { Whitney, } \\
\text { Kruskal- } \\
\text { Wallis }\end{array}$ & $\begin{array}{l}\mathrm{dmft}=4.7 \\
\mathrm{dmfs}=8 . C\end{array}$ \\
\hline Age & + & $\begin{array}{l}\text { Dogan et al. } \\
2013(28) \\
\text { (CS) }\end{array}$ & Turkey & Primary & 3171 & $\begin{array}{l}8-60 \text { mo } \\
(M, F)\end{array}$ & Clinic & WHO (dft) & Chi-Square & $\begin{array}{l}\text { ECCP }=17 . \\
d f t=0.63\end{array}$ \\
\hline Age & + & $\begin{array}{l}\text { Namal et al. } \\
2005 \text { (29) } \\
\text { (CS) }\end{array}$ & Turkey & Primary & 598 & $\begin{array}{l}3-6 y \\
(M, F)\end{array}$ & School & WHO (dft) & $\begin{array}{l}\text { Multiple } \\
\text { logistic } \\
\text { regression }\end{array}$ & $\mathrm{dft}=74.1 \%$ \\
\hline Age & + & $\begin{array}{l}\text { Olmez et al. } \\
2003(30) \\
\text { (CS) }\end{array}$ & Turkey & Primary & 95 & $\begin{array}{l}9-57 \mathrm{mo} \\
(\mathrm{M}, \mathrm{F})\end{array}$ & Clinic & $\mathrm{WHO}(\mathrm{dft})$ & $\begin{array}{l}\text { Chi-Square, } \\
\text { Kruskal- } \\
\text { Wallis }\end{array}$ & $\begin{array}{l}\mathrm{DCP}=75.5 \\
\mathrm{dft}=6.2\end{array}$ \\
\hline Age & + & $\begin{array}{l}\text { Bener et al. } \\
2013 \text { (15) } \\
\text { (CS) }\end{array}$ & Qatar & Permanent & 1284 & $\begin{array}{l}6-15 y \\
(M, F)\end{array}$ & Clinic & WHO (DMFT) & $\begin{array}{l}\text { Multivariate } \\
\text { analysis }\end{array}$ & $\begin{array}{l}\mathrm{DCP}=73 \% \\
\mathrm{DMFT}=4 . !\end{array}$ \\
\hline Age & Unclear & $\begin{array}{l}\text { Khadri et al. } \\
2018(16) \\
\text { (CS) }\end{array}$ & UAE & Permanent & 803 & $\begin{array}{l}11-17 y \\
(M, F)\end{array}$ & School & WHO (DMFT) & $\begin{array}{l}\text { Multivariate } \\
\text { regression }\end{array}$ & $\begin{array}{l}\mathrm{DCP}=75 \% \\
\mathrm{DMFT}=3 . \\
2.9)\end{array}$ \\
\hline Age & + & $\begin{array}{l}\text { Hashim et al. } \\
2006(9) \\
\text { (CS) }\end{array}$ & UAE & Primary & 1036 & $\begin{array}{l}5,6 \mathrm{y} \\
(\mathrm{M}, \mathrm{F})\end{array}$ & School & $\begin{array}{l}\text { WHO (dmft, } \\
\text { dmfs) }\end{array}$ & $\begin{array}{l}\text { Chi-Square, } \\
\text { ZINB } \\
\text { regression }\end{array}$ & $\begin{array}{l}\mathrm{DCP}=76.1 \\
\mathrm{dmft}=4.4 \\
\mathrm{dmfs}=10 .\end{array}$ \\
\hline
\end{tabular}

\section{Weight \\ status}

Over weight +

Jahani et al. Iran

Primary

845

2013 (12)

Permanent

School

WHO

(dmft/DMFT)

Ordina

registic

Moderate

(CS)

BMI

Bagherian
Sadeghi,

Primary

$(\mathrm{M}, \mathrm{F})$

Not WHO (defs) Multiple

logistic
regression

regression $\mathrm{S}-\mathrm{ECCP}=5$

(CS)

$(\mathrm{M}, \mathrm{F}) \quad$ specified

defs $=8.37$

11.2)

$\mathrm{BMI}+\quad \begin{aligned} & \text { Abu El } \\ & \text { Qomsan et } \\ & \text { al. } 2017 \text { (32) }\end{aligned}$

KSA

KSA Permanent 386

6-12y

(M, F)

School and

Clinic

WHO (DM
DT, FT)

(CS)

One-way
ANOVA,
Spearman's

DT:

Underweis

(SD 1.48)

Normal

weight $=2$.

2.34)

Over weig

(SD 2.39)

Obese $=4$. 1

2.57)

FT:

Underweic

(SD 0.68)

Normal

weight $=0$.

0.95)

Over weig

(SD 0.70)

Obese $=0.6$

1.18) 


\begin{tabular}{|c|c|c|c|c|c|c|c|c|c|c|}
\hline BMI & - & $\begin{array}{l}\text { Alghamdi \& } \\
\text { Almahdy, } \\
2017 \text { (33) } \\
\text { (CS) }\end{array}$ & KSA & Permanent & 610 & $\begin{array}{l}14-16 y \\
(M)\end{array}$ & School & $\begin{array}{l}\text { Not specified } \\
\text { DMFT }\end{array}$ & $\begin{array}{l}\text { Logistic } \\
\text { regression }\end{array}$ & $\mathrm{DCP}=54.1$ \\
\hline Low BMI & + & $\begin{array}{l}\text { Quadri et al. } \\
2017 \text { (34) } \\
\text { (CS) }\end{array}$ & KSA & $\begin{array}{l}\text { Primary } \\
\text { Permanent }\end{array}$ & 360 & $\begin{array}{l}6-15 y \\
(M, F)\end{array}$ & School & $\begin{array}{l}\text { WHO } \\
\text { (dft/DMFT) }\end{array}$ & $\begin{array}{l}\text { Logistic } \\
\text { regression }\end{array}$ & $\begin{array}{l}\text { dft/DMFT } \\
2.52(\mathrm{~F}) \\
1.88(\mathrm{M})\end{array}$ \\
\hline BMI & - & $\begin{array}{l}\text { Goodson et } \\
\text { al. } 2013 \text { (8) } \\
\text { (CS) }\end{array}$ & Kuwait & $\begin{array}{l}\text { Primary } \\
\text { Mixed } \\
\text { Permanent }\end{array}$ & 8,319 & $\begin{array}{l}\text { Mean } \\
\text { age=11.36 } \\
\text { y (grade } 4 \\
\& 5) \\
(M, F)\end{array}$ & School & $\begin{array}{l}\text { Percentage } \\
\text { of decayed or } \\
\text { filled teeth }^{1}\end{array}$ & $\begin{array}{l}\text { Multivariate } \\
\text { rank-based } \\
\text { Wilcoxon } \\
\text { regression }\end{array}$ & $\begin{array}{l}\text { Decayed c } \\
\text { teeth (all } \mathrm{k} \\
\text { weights) } \\
=11.01 \% \text { ( } \\
0.11 \text { ) } \\
\text { Decayed c } \\
\text { teeth } \\
\text { (males) }=1 \\
\text { (SEM 0.1 } \\
\text { Decayed c } \\
\text { teeth } \\
\text { (females) } \\
\text { (SEM } 0.1<\end{array}$ \\
\hline Under weight & + & $\begin{array}{l}\text { Köksal et al. } \\
2011 \text { (35) } \\
\text { (CS) }\end{array}$ & Turkey & $\begin{array}{l}\text { Primary } \\
\text { Permanent }\end{array}$ & 245 & $\begin{array}{l}5-6 y \\
(M . F)\end{array}$ & Unclear & $\begin{array}{l}\text { WHO (dmft, } \\
\text { DMFT, dmfs) }\end{array}$ & $\begin{array}{l}\text { Chi-Square, } \\
\text { Mann- } \\
\text { Whitney, } \\
\text { Spearman's }\end{array}$ & $\begin{array}{l}\mathrm{DCP}=85.9 \\
\mathrm{dmft}=5.3 \\
3.78) \\
\text { DMFT }=0 . \\
0.74) \\
\mathrm{dmfs}=10 . \\
9.67) \\
\\
\text { DMFS }=0 . \\
0.95)\end{array}$ \\
\hline $\begin{array}{l}\text { Weight } \\
\text { status }\end{array}$ & Varied $^{d}$ & $\begin{array}{l}\text { Bhayat et al. } \\
2016(36) \\
\text { (CS) }\end{array}$ & KSA & Permanent & 402 & $\begin{array}{l}12 y \\
(M)\end{array}$ & School & $\begin{array}{l}\text { WHO } \\
\text { (DMFT) }\end{array}$ & $\begin{array}{l}\text { Linear } \\
\text { regression }\end{array}$ & $\begin{array}{l}\mathrm{DCP}=49 \% \\
\mathrm{DMFT}=1.4 \\
2.04)\end{array}$ \\
\hline BMI & + & $\begin{array}{l}\text { Bener et al. } \\
2013 \text { (15) } \\
\text { (CS) }\end{array}$ & Qatar & Permanent & 1284 & $\begin{array}{l}6-15 y \\
(M, F)\end{array}$ & Clinic & WHO (DMFT) & $\begin{array}{l}\text { Multivariate } \\
\text { analysis }\end{array}$ & $\begin{array}{l}\mathrm{DCP}=73 \% \\
\mathrm{DMFT}=4 . !\end{array}$ \\
\hline
\end{tabular}

AAPD American Association Paediatric Dentistry, BASCD British Association for the Study of Community Dentistry, CS Cross-sectional, CC Case control, DCP Dental caries prevalence, deft decayed, extracted due to caries and filled primary teeth, $d f s$ decayed, filled surfaces in primary teeth, $d f t$ decayed, filled primary teeth, $d m f s$ decayed, missing and filled surfaces in primary teeth; DMFS decayed, missing and filled surfaces in permanent teeth, $d m f t$ decayed, missing, filled primary teeth, DMFT decayed, missing, filled permanent teeth, ECC Early childhood caries, ECCP Early childhood caries prevalence, $F$ Female, ICADS The international caries Detection and Assessment System, $L$ Longitudinal, KSA Kingdom of Saudi Arabia, $m$ months $M$ Male, WHO World Health Organisation, SiC Significant caries index, SD Standard deviation, $y$ years

${ }^{a}$ The author calculated this as follows the decayed or filled teeth $(\%)=100 \times[$ (number of primary teeth with fillings) +(number of permanent teeth with fillings) + (number of decayed primary teeth)+(number decayed permanent teeth)]/[(number of primary teeth)+(number of permanent teeth)].

${ }^{b}$ The children were categorized into three groups on the basis of WHO caries severity classification. Low caries level was defined as dmft/DMFT $\leq 2.6$, moderate caries as dmft/DMFT of 2.7-4.4 and high caries as dmft/DMFT >4.4.

'Sayegh et al. 2002 and Sayegh et al. 2005 seem to be based on the same study population and the results mentioned in this table, have been reported in both articles.

${ }^{\mathrm{d}}$ Normal weight status-positive association to caries, whereas the caries prevalence was lower in under and overweight children

Table 3 Statistically significant socio-economic, socio-demographic, school type and geographical-related determinants contributing to dental caries 


\begin{tabular}{|c|c|c|c|c|c|c|c|c|c|c|}
\hline Determinants & $\begin{array}{l}\text { Association: } \\
\text { Positive (+), } \\
\text { Negative (-) }\end{array}$ & $\begin{array}{l}\text { Author } \\
\text { Study design }\end{array}$ & Country & $\begin{array}{l}\text { Type of } \\
\text { dentition }\end{array}$ & $\mathbf{N}$ & $\begin{array}{l}\text { Age } \\
\text { group } \\
\text { (Gender) }\end{array}$ & $\begin{array}{l}\text { Study } \\
\text { setting }\end{array}$ & $\begin{array}{l}\text { Scoring } \\
\text { system }\end{array}$ & $\begin{array}{l}\text { Type/s of } \\
\text { statistical } \\
\text { analysis }\end{array}$ & $\begin{array}{l}\text { Dental caries/ } \\
\text { scoring result }\end{array}$ \\
\hline \multicolumn{11}{|l|}{$\begin{array}{l}\text { Mother's } \\
\text { attributes }\end{array}$} \\
\hline $\begin{array}{l}\text { Mother's } \\
\text { education }\end{array}$ & - & $\begin{array}{l}\text { Abu Hamila, } \\
2013(1) \\
\text { (CS) }\end{array}$ & Egypt & Primary & 560 & $\begin{array}{l}1-3.5 y \\
(M, F)\end{array}$ & Clinic & $\begin{array}{l}\text { WHO } \\
\text { (dmft) }\end{array}$ & Chi-Square & $\begin{array}{l}\mathrm{ECCP}=69.6 \% \\
\mathrm{dmft}=2.1-7.6\end{array}$ \\
\hline $\begin{array}{l}\text { Mother's } \\
\text { education }\end{array}$ & - & $\begin{array}{l}\text { Bashirian et } \\
\text { al. } 2018(2) \\
(\mathrm{CS})\end{array}$ & Iran & $\begin{array}{l}\text { Primary } \\
\text { Permanent }\end{array}$ & 988 & $\begin{array}{l}7-12 y \\
(M, F)\end{array}$ & School & $\begin{array}{l}\text { WHO } \\
\text { (dmft, } \\
\text { DMFT) }\end{array}$ & ANOVA & $\begin{array}{l}\mathrm{DCP}=80.36 \% \\
\mathrm{dmft}=3.61 \\
\text { DMFT }=0.79\end{array}$ \\
\hline $\begin{array}{l}\text { Mother's } \\
\text { education }\end{array}$ & - & $\begin{array}{l}\text { Shaghaghian } \\
\text { et al. } 2018 \\
\text { (3) } \\
\text { (CS) }\end{array}$ & Iran & Primary & 396 & $\begin{array}{l}3-6 y \\
(M, F)\end{array}$ & School & $\begin{array}{l}\text { WHO } \\
\text { (dmft) }\end{array}$ & $\begin{array}{l}\text { Multivariate } \\
\text { analysis }\end{array}$ & $\begin{array}{l}\mathrm{DCP}=69.9 \% \\
\mathrm{dmft}=3.88\end{array}$ \\
\hline $\begin{array}{l}\text { Mother's } \\
\text { education }\end{array}$ & - & $\begin{array}{l}\text { Haghdoost et } \\
\text { al. } 2017(4) \\
\text { (CS) }\end{array}$ & Iran & $\begin{array}{l}\text { Primary } \\
\text { Permanent }\end{array}$ & 8725 & $\begin{array}{l}6 y \\
(M, F)\end{array}$ & Clinic & WHO & $\begin{array}{l}\text { Linear } \\
\text { regression, } \\
\text { Logistic } \\
\text { regression }\end{array}$ & $\mathrm{DCP}=87 \%$ \\
\hline $\begin{array}{l}\text { Mother's } \\
\text { education }\end{array}$ & - & $\begin{array}{l}\text { Khani- } \\
\text { Varzegani et } \\
\text { al. } 2017 \text { (5) } \\
\text { (CS) }\end{array}$ & Iran & Primary & 756 & $\begin{array}{l}4-7 y \\
(M, F)\end{array}$ & School & $\begin{array}{l}\text { WHO } \\
\text { (dmft) }\end{array}$ & $\begin{array}{l}\text { Multivariate } \\
\text { analysis }\end{array}$ & $\begin{array}{l}\text { dmft median } \\
\text { (25th-75th } \\
\text { percentile): } \\
\text { All=4(2-8) } \\
\text { Males= 4(2-9) } \\
\text { Females=5(2- } \\
8)\end{array}$ \\
\hline $\begin{array}{l}\text { Mother's } \\
\text { education } \\
\text { (low levels) }\end{array}$ & + & $\begin{array}{l}\text { Alhabdan et } \\
\text { al. } 2018 \text { (6) } \\
\text { (CS) }\end{array}$ & KSA & Primary & 578 & $\begin{array}{l}6-8 y \\
(M, F)\end{array}$ & School & $\begin{array}{l}\text { WHO } \\
\text { (dmft) }\end{array}$ & $\begin{array}{l}\text { Adjusted } \\
\text { Odds } \\
\text { Ratios } \\
\text { Multivariate } \\
\text { model } \\
\text { logistic } \\
\text { regression }\end{array}$ & $\begin{array}{l}\text { DCCP }=83 \% \\
\text { dmft } 4.20(S D \\
2.96)\end{array}$ \\
\hline $\begin{array}{l}\text { Mother's } \\
\text { education }\end{array}$ & - & $\begin{array}{l}\text { Al-Meedani, } \\
2016(7) \\
(\mathrm{CS})\end{array}$ & KSA & Primary & 388 & $\begin{array}{l}3-5 y \\
(M, F)\end{array}$ & School & $\begin{array}{l}\text { WHO } \\
\text { (dmft, } \\
\text { dmfs) }\end{array}$ & $\begin{array}{l}\text { Chi-Square } \\
\text { Z-test }\end{array}$ & $\begin{array}{l}\mathrm{DCP}=69 \% \\
\mathrm{dmft}=3.4 \\
\mathrm{dmfs}=6.9\end{array}$ \\
\hline $\begin{array}{l}\text { Mother's } \\
\text { education }\end{array}$ & - & $\begin{array}{l}\text { Quadri et al. } \\
2015 \text { (8) } \\
\text { (CS) }\end{array}$ & KSA & $\begin{array}{l}\text { Primary } \\
\text { Permanent }\end{array}$ & 853 & $\begin{array}{l}6-15 y \\
(M, F)\end{array}$ & School & $\begin{array}{l}\text { WHO } \\
\text { (dft, } \\
\text { DMFT) }\end{array}$ & $\begin{array}{l}\text { Multi } \\
\text { regression }\end{array}$ & $D C P=91.3 \%$ \\
\hline $\begin{array}{l}\text { Mother's } \\
\text { education }\end{array}$ & - & $\begin{array}{l}\text { Al-Malik et al. } \\
2002(9) \\
(\mathrm{CS})\end{array}$ & KSA & Primary & 987 & $\begin{array}{l}2-5 y \\
(M, F)\end{array}$ & School & $\begin{array}{l}\text { BASCD } \\
\text { (dmft, } \\
\text { dmfs) }\end{array}$ & $\begin{array}{l}\text { Stepwise } \\
\text { multiple } \\
\text { logistic } \\
\text { regression }\end{array}$ & 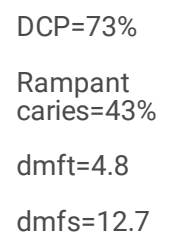 \\
\hline $\begin{array}{l}\text { Mother's } \\
\text { education } \\
\text { (number of } \\
\text { filled teeth in } \\
\text { the child) }\end{array}$ & + & $\begin{array}{l}\text { Azizi et al. } \\
2014(10) \\
\text { (CS) }\end{array}$ & Palestine & Primary & 1376 & $\begin{array}{l}4-6 y \\
(M, F)\end{array}$ & Clinic & $\begin{array}{l}\text { WHO } \\
\text { (dmft) }\end{array}$ & $\begin{array}{l}\text { Not } \\
\text { indicated }\end{array}$ & $\begin{array}{l}\mathrm{DCP}=76 \% \\
\mathrm{dmft}=2.46\end{array}$ \\
\hline $\begin{array}{l}\text { Mother's } \\
\text { education }\end{array}$ & - & $\begin{array}{l}\text { Ozer et al. } \\
2011(11) \\
(\mathrm{CS})\end{array}$ & Turkey & Primary & 226 & $\begin{array}{l}3-6 y \\
(M, F)\end{array}$ & School & $\begin{array}{l}\text { WHO } \\
(\mathrm{dmft}) \\
\text { AAPD }\end{array}$ & $\begin{array}{l}\text { Bivariate } \\
\text { analysis }\end{array}$ & $\begin{array}{l}\mathrm{ECCP}=46.9 \% \\
\mathrm{dmft}=2.87\end{array}$ \\
\hline Mother's & - & $\begin{array}{l}\text { Namal et al. } \\
2009(12)\end{array}$ & Turkey & Primary & 542 & $5-6 y$ & School & $\begin{array}{l}\text { WHO } \\
\text { (dmft) }\end{array}$ & $\begin{array}{l}\text { Multiple } \\
\text { logistic }\end{array}$ & $D C P=76.8 \%$ \\
\hline
\end{tabular}




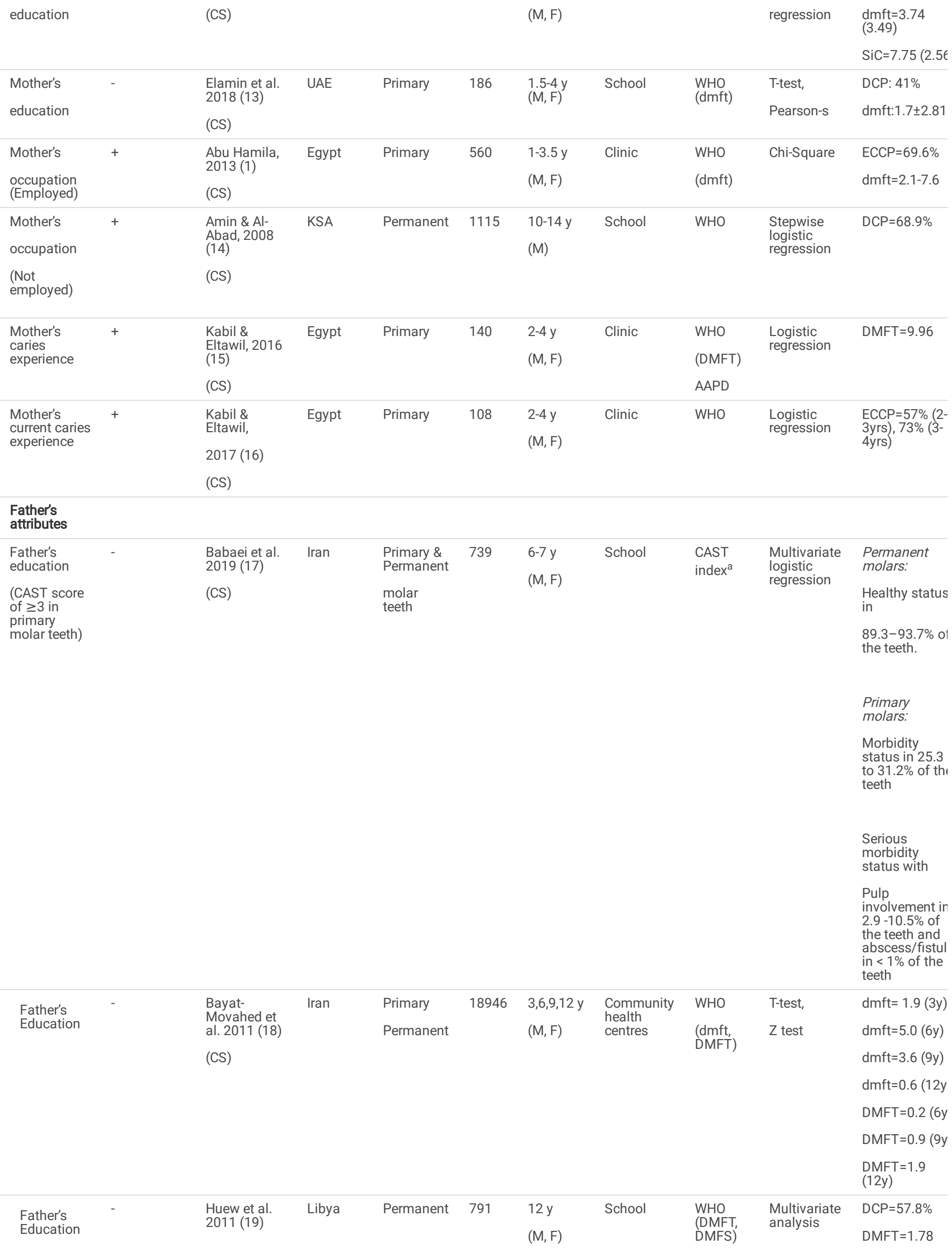


(CS)

DMFS $=2.39$

\begin{tabular}{|c|c|c|c|c|c|c|c|c|c|c|}
\hline $\begin{array}{l}\text { Father's } \\
\text { Education }\end{array}$ & Unclear & $\begin{array}{l}\text { Khadri et al. } \\
2018 \text { (20) } \\
\text { (CS) }\end{array}$ & UAE & Permanent & 803 & $\begin{array}{l}11-17 y \\
(M, F)\end{array}$ & School & $\begin{array}{l}\text { WHO } \\
\text { (DMFT) }\end{array}$ & $\begin{array}{l}\text { Multivariate } \\
\text { regression }\end{array}$ & $\begin{array}{l}\text { DCP }=75 \% \\
\text { DMFT }=3.19 \\
(\text { SD 2.9) }\end{array}$ \\
\hline $\begin{array}{l}\text { Father's } \\
\text { Occupation }\end{array}$ & + & $\begin{array}{l}\text { Shaghaghian } \\
\text { et al. } 2018 \\
\text { (3) } \\
\text { (CS) }\end{array}$ & Iran & Primary & 396 & $\begin{array}{l}3-6 y \\
(M, F)\end{array}$ & School & $\begin{array}{l}\text { WHO } \\
\text { (dmft) }\end{array}$ & $\begin{array}{l}\text { Multivariate } \\
\text { analysis }\end{array}$ & $\begin{array}{l}\mathrm{DCP}=69.9 \% \\
\mathrm{dmft}=3.88\end{array}$ \\
\hline $\begin{array}{l}\text { Father's } \\
\text { occupation } \\
\text { (Low } \\
\text { educational } \\
\text { occupations) }\end{array}$ & + & $\begin{array}{l}\text { Namal et al. } \\
2005(21) \\
(\mathrm{CS})\end{array}$ & Turkey & Primary & 598 & $\begin{array}{l}3-6 y \\
(M, F)\end{array}$ & School & $\begin{array}{l}\text { WHO } \\
\text { (dft) }\end{array}$ & $\begin{array}{l}\text { Multiple } \\
\text { logistic } \\
\text { regression }\end{array}$ & $\mathrm{DCP}=74.1 \%$ \\
\hline $\begin{array}{l}\text { Father's } \\
\text { occupation } \\
\text { (Self- }\end{array}$ & + & $\begin{array}{l}\text { Amanlou et } \\
\text { al. } 2011(22) \\
\text { (CS) }\end{array}$ & Iran & $\begin{array}{l}\text { Primary } \\
\text { Permanent }\end{array}$ & 205 & $\begin{array}{l}3-6 y \\
(M, F)\end{array}$ & School & $\begin{array}{l}\text { WHO } \\
(\text { DMFT) })^{b}\end{array}$ & $\begin{array}{l}\text { Stepwise } \\
\text { multiple } \\
\text { regression }\end{array}$ & $\begin{array}{l}\mathrm{DCP}=49.3 \% \\
\text { DMFT }=0.99 \\
(\text { SD 0.13) }\end{array}$ \\
\hline
\end{tabular}

\section{Parents}

attributes

\begin{tabular}{|c|c|c|c|c|c|c|c|c|c|c|}
\hline $\begin{array}{l}\text { Parents' } \\
\text { education } \\
\text { (primary } \\
\text { dentition) }\end{array}$ & - & $\begin{array}{l}\text { Abbass et al. } \\
2019 \text { (23) } \\
(\mathrm{CS})\end{array}$ & Egypt & $\begin{array}{l}\text { Primary. } \\
\text { Mixed, } \\
\text { Permanent }\end{array}$ & 369 & $\begin{array}{l}3-18 y \\
(M, F)\end{array}$ & Clinic & $\begin{array}{l}\text { WHO } \\
\text { (dmft, } \\
\text { deft, } \\
\text { DMFT) }\end{array}$ & $\begin{array}{l}\text { Kruskal- } \\
\text { Wallis, } \\
\text { Spearman's }\end{array}$ & $\begin{array}{l}\mathrm{DCP}=74 \% \\
\mathrm{dmft}=3.23(\mathrm{~S}[ \\
4.07) \\
\text { deft }=4.21(\mathrm{SD} \\
3.21)\end{array}$ \\
\hline & & & & & & & & & & $\begin{array}{l}\text { DMFT }=1.04 \\
(S D 1.56)\end{array}$ \\
\hline $\begin{array}{l}\text { Parents' } \\
\text { education } \\
\text { level }\end{array}$ & - & $\begin{array}{l}\text { Sistani et al, } \\
2017(24) \\
(C S)^{c}\end{array}$ & Iran & Primary & 2080 & $\begin{array}{l}3-6 y \\
(M, F)\end{array}$ & School & $\begin{array}{l}\text { WHO } \\
\text { (dmft) }\end{array}$ & $\begin{array}{l}\text { T-test, } \\
\text { ANOVA }\end{array}$ & $\begin{array}{l}\text { ECCP varied } \\
\text { between } \\
51.1 \%-71.9 \% \\
\text { during } 2007- \\
2015\end{array}$ \\
\hline & & & & & & & & & & $\begin{array}{l}\mathrm{dmft}=4.01(\mathrm{~S}[ \\
3.89)\end{array}$ \\
\hline $\begin{array}{l}\text { Socio- } \\
\text { economic } \\
\text { factors }^{d}\end{array}$ & + & $\begin{array}{l}\text { Ahmed et al. } \\
2007 \text { (25) }\end{array}$ & Iraq & Permanent & 392 & $\begin{array}{l}12 \mathrm{y} \\
(\mathrm{M}, \mathrm{F})\end{array}$ & School & $\begin{array}{l}\text { WHO } \\
\text { (DMFT) }\end{array}$ & ANOVA & $\begin{array}{l}\mathrm{DCP}=62 \% \\
\mathrm{DMFT}=1.7\end{array}$ \\
\hline
\end{tabular}

\begin{tabular}{|c|c|c|c|c|c|c|c|c|c|c|}
\hline $\begin{array}{l}\text { Parents' } \\
\text { Education }\end{array}$ & - & $\begin{array}{l}\text { Al- } \\
\text { Mendalawi \& } \\
\text { Karam, } 2014 \\
(26) \\
(\mathrm{CC})\end{array}$ & Iraq & Primary & 684 & $\begin{array}{l}<6 y \\
(M, F)\end{array}$ & Clinic & $\begin{array}{l}\text { WHO } \\
(\mathrm{DMFT})^{\mathrm{e}}\end{array}$ & Chi-Square & $\mathrm{DMFT}=2.03$ \\
\hline $\begin{array}{l}\text { Parents } \\
\text { Education }\end{array}$ & - & $\begin{array}{l}\text { Rajab et al. } \\
2014 \text { (27) } \\
\text { (CS) }\end{array}$ & Jordan & $\begin{array}{l}\text { Primary } \\
\text { Permanent }\end{array}$ & $\begin{array}{l}2496 \\
(6 \mathrm{y}) \\
2560 \\
(12 \mathrm{y})\end{array}$ & $\begin{array}{l}6 y, 12 y \\
(M, F)\end{array}$ & School & $\begin{array}{l}\text { WHO } \\
\text { (dmft, } \\
\text { DMFT) }\end{array}$ & $\begin{array}{l}\text { Multivariate } \\
\text { analysis } \\
\text { linear } \\
\text { regression }\end{array}$ & $\begin{array}{l}\text { DCP }=76.4 \%(6 \\
y) \\
\text { DCP }=45.5 \%(1 \\
y) \\
d m f t=3.3(6 y) \\
\text { DMFT }=1.1(12 \\
y)\end{array}$ \\
\hline $\begin{array}{l}\text { Parents' } \\
\text { employment } \\
\text { status }\end{array}$ & - & $\begin{array}{l}\text { Sistani et al, } \\
2017(24) \\
(\mathrm{CS})^{\mathrm{c}}\end{array}$ & Iran & Primary & 2080 & $\begin{array}{l}3-6 y \\
(M, F)\end{array}$ & School & $\begin{array}{l}\text { WHO } \\
\text { (dmft) }\end{array}$ & $\begin{array}{l}\text { T-test, } \\
\text { ANOVA }\end{array}$ & $\begin{array}{l}\text { ECCP varied } \\
\text { between } \\
51.1 \%-71.9 \% \\
\text { during 2007- } \\
2015 \\
\text { dmft=4.01 (SC } \\
3.89)\end{array}$ \\
\hline $\begin{array}{l}\text { Parents' } \\
\text { employment } \\
\text { status }\end{array}$ & - & $\begin{array}{l}\text { Khodadadi et } \\
\text { al. } \\
2016(28)\end{array}$ & Iran & Primary & 384 & $\begin{array}{l}21-84 \\
\text { mo } \\
(\mathrm{M}, \mathrm{F})\end{array}$ & $\begin{array}{l}\text { Not } \\
\text { specified }\end{array}$ & $\begin{array}{l}\text { WHO } \\
\text { (dmft) }\end{array}$ & $\begin{array}{l}\text { Multiple } \\
\text { linear } \\
\text { regression }\end{array}$ & $\mathrm{dmft}=8.2$ \\
\hline
\end{tabular}

(CS) 


\begin{tabular}{|c|c|c|c|c|c|c|c|c|c|c|}
\hline \multirow[t]{2}{*}{$\begin{array}{l}\text { Socio- } \\
\text { economic } \\
\text { status }^{f}\end{array}$} & \multirow[t]{2}{*}{-} & \multirow[t]{2}{*}{$\begin{array}{l}\text { Abbass et al. } \\
2019(23) \\
(\mathrm{CS})\end{array}$} & \multirow[t]{2}{*}{ Egypt } & \multirow[t]{2}{*}{$\begin{array}{l}\text { Primary. } \\
\text { Mixed, } \\
\text { Permanent }\end{array}$} & \multirow[t]{2}{*}{369} & \multirow[t]{2}{*}{$\begin{array}{l}3-18 y \\
(M, F)\end{array}$} & \multirow[t]{2}{*}{ Clinic } & \multirow[t]{2}{*}{$\begin{array}{l}\text { WHO } \\
\text { (dmft, } \\
\text { deft, } \\
\text { DMFT) }\end{array}$} & \multirow[t]{2}{*}{$\begin{array}{l}\text { Kruskal- } \\
\text { Wallis, } \\
\text { Spearman's }\end{array}$} & \multirow{2}{*}{$\begin{array}{l}\text { DCP }=74 \% \\
\text { dmft=3.23 (SE } \\
4.07) \\
\text { deft }=4.21(\mathrm{SD} \\
3.21) \\
\\
\text { DMFT }=1.04 \\
(\mathrm{SD} 1.56)\end{array}$} \\
\hline & & & & & & & & & & \\
\hline $\begin{array}{l}\text { Family } \\
\text { affluent scale }\end{array}$ & - & $\begin{array}{l}\text { Khani- } \\
\text { Varzegani et } \\
\text { al. } 2017 \text { (5) }\end{array}$ & Iran & Primary & 756 & $\begin{array}{l}4-7 y \\
(M, F)\end{array}$ & School & WHO & $\begin{array}{l}\text { Multivariate } \\
\text { analysis }\end{array}$ & $\begin{array}{l}\text { dmft median } \\
\text { (25th-75th } \\
\text { percentile): }\end{array}$ \\
\hline & & (CS) & & & & & & & & All=4(2-8) \\
\hline & & & & & & & & & & Boys $=4(2-9)$ \\
\hline & & & & & & & & & & Girls $=5(2-8)$ \\
\hline Income & - & $\begin{array}{l}\text { Al- } \\
\text { Mendalawi \& } \\
\text { Karam, } 2014 \\
(26)\end{array}$ & Iraq & Primary & 684 & $\begin{array}{l}<6 y \\
(M, F)\end{array}$ & Clinic & $\begin{array}{l}\text { WHO } \\
(\text { DMFT })^{e}\end{array}$ & Chi-Square & $\mathrm{DMFT}=2.03$ \\
\hline & & (CC) & & & & & & & & \\
\hline $\begin{array}{l}\text { Low family } \\
\text { income }\end{array}$ & + & $\begin{array}{l}\text { Alhabdan et } \\
\text { al. } 2018 \text { (6) } \\
\text { (CS) }\end{array}$ & KSA & Primary & 578 & $\begin{array}{l}6-8 y \\
(M)\end{array}$ & School & $\begin{array}{l}\text { WHO } \\
\text { (dmft) }\end{array}$ & $\begin{array}{l}\text { Adjusted } \\
\text { Odds } \\
\text { Ratios, } \\
\text { Multivariate } \\
\text { model } \\
\text { logistic } \\
\text { regression }\end{array}$ & $\begin{array}{l}\text { DCCP }=83 \% \\
\text { dmft } 4.20(S D \\
2.96)\end{array}$ \\
\hline $\begin{array}{l}\text { Lack of } \\
\text { dental } \\
\text { insurance- }\end{array}$ & + & $\begin{array}{l}\text { Alhabdan et } \\
\text { al. } 2018 \text { (6) } \\
\text { (CS) }\end{array}$ & KSA & Primary & 578 & $\begin{array}{l}6-8 y \\
(M)\end{array}$ & School & $\begin{array}{l}\text { WHO } \\
(\mathrm{dmft})\end{array}$ & $\begin{array}{l}\text { Adjusted } \\
\text { Odds } \\
\text { Ratios, } \\
\text { Multivariate } \\
\text { model } \\
\text { logistic } \\
\text { regression }\end{array}$ & $\begin{array}{l}\mathrm{DCCP}=83 \% \\
\mathrm{dmft} 4.20(\mathrm{SD} \\
\pm 2.96)\end{array}$ \\
\hline $\begin{array}{l}\text { Socio- } \\
\text { Economic } \\
\text { Status }^{8}\end{array}$ & - & $\begin{array}{l}\text { Alghamdi \& } \\
\text { Almahdy, } \\
2017 \text { (29) } \\
\text { (CS) }\end{array}$ & KSA & Permanent & 610 & $\begin{array}{l}14-16 y \\
(M)\end{array}$ & School & $\begin{array}{l}\text { Not } \\
\text { specified } \\
\text { (DMFT) }\end{array}$ & $\begin{array}{l}\text { Logistic } \\
\text { regression }\end{array}$ & $\mathrm{DCP}=54.1 \%$ \\
\hline $\begin{array}{l}\text { Socio- } \\
\text { Economic } \\
\text { Status }^{h}\end{array}$ & - & $\begin{array}{l}\text { Rajab et al. } \\
2014 \\
(27) \\
\text { (CS) }\end{array}$ & Jordan & $\begin{array}{l}\text { Primary } \\
\text { Permanent }\end{array}$ & $\begin{array}{l}2496 \\
(6 \mathrm{y}) \\
2560 \\
(12 \mathrm{y})\end{array}$ & $\begin{array}{l}6 y, 12 y \\
(M, F)\end{array}$ & School & $\begin{array}{l}\text { WHO } \\
\text { (dmft, } \\
\text { DMFT) }\end{array}$ & $\begin{array}{l}\text { Multivariate } \\
\text { analysis } \\
\text { linear } \\
\text { regression }\end{array}$ & $\begin{array}{l}\text { DCP }=76.4 \%(6 \\
y) \\
D C P=45.5 \%(1 \\
y) \\
d m f t=3.3(6 y) \\
\begin{array}{l}\text { DMFT }=1.1(12 \\
\text { y) }\end{array}\end{array}$ \\
\hline $\begin{array}{l}\text { Household } \\
\text { income }\end{array}$ & + & $\begin{array}{l}\text { Bener et al. } \\
2013 \text { (30) } \\
\text { (CS) }\end{array}$ & Qatar & Permanent & 1284 & $\begin{array}{l}6-15 y \\
(M, F)\end{array}$ & Clinic & $\begin{array}{l}\text { WHO } \\
\text { (DMFT) }\end{array}$ & $\begin{array}{l}\text { Multivariate } \\
\text { analysis }\end{array}$ & $\begin{array}{l}\mathrm{DCP}=73 \% \\
\mathrm{DMFT}=4.5\end{array}$ \\
\hline $\begin{array}{l}\text { House Hold } \\
\text { Income }\end{array}$ & - & $\begin{array}{l}\text { Hashim et al. } \\
2011(31) \\
\text { (CS) }\end{array}$ & UAE & Primary & 1036 & $\begin{array}{l}3-6 y \\
(M, F)\end{array}$ & School & WHO & $\begin{array}{l}\text { Logistic } \\
\text { regression }\end{array}$ & $\begin{array}{l}\text { Severe } \\
\text { ECCP }=31.1 \%\end{array}$ \\
\hline
\end{tabular}

Family

demographic

\begin{tabular}{|c|c|c|c|c|c|c|c|c|c|c|}
\hline Sibling order & Varied $^{\mathrm{i}}$ & $\begin{array}{l}\text { Abu Hamila, } \\
2013 \text { (1) } \\
\text { (CS) }\end{array}$ & Egypt & Primary & 560 & $\begin{array}{l}1-3.5 y \\
(M, F)\end{array}$ & Clinic & $\begin{array}{l}\text { WHO } \\
\text { (dmft) }\end{array}$ & Chi-Square & $\begin{array}{l}\mathrm{ECCP}=69.6 \% \\
\mathrm{dmft}=2.1-7.6\end{array}$ \\
\hline $\begin{array}{l}\text { Number of } \\
\text { Siblings }\end{array}$ & + & $\begin{array}{l}\text { Shaghaghian } \\
\text { et al. } 2018 \\
\text { (3) } \\
\text { (CS) }\end{array}$ & Iran & Primary & 396 & $\begin{array}{l}3-6 y \\
(M, F)\end{array}$ & School & $\begin{array}{l}\text { WHO } \\
\text { (dmft) }\end{array}$ & $\begin{array}{l}\text { Multivariate } \\
\text { analysis }\end{array}$ & $\begin{array}{l}\mathrm{DCP}=69.9 \% \\
\mathrm{dmft}=3.88\end{array}$ \\
\hline $\begin{array}{l}\text { Large family } \\
\text { size }\end{array}$ & + & $\begin{array}{l}\text { Al-Meedani, } \\
2016(7)\end{array}$ & Iraq & Primary & 684 & $0-6 y$ & Clinic & WHO & Chi-Square, & $\mathrm{DCP}=69 \%$ \\
\hline
\end{tabular}




\begin{tabular}{|c|c|c|c|c|c|c|c|c|c|c|}
\hline & & (CS) & & & & $(\mathrm{M}, \mathrm{F})$ & & $\begin{array}{l}\text { (dmft, } \\
\text { dmfs) }\end{array}$ & Z-test & $\begin{array}{l}\mathrm{dmft}=3.4 \\
\mathrm{dmfs}=6.9\end{array}$ \\
\hline $\begin{array}{l}\text { Large family } \\
\text { size }\end{array}$ & + & $\begin{array}{l}\text { Amin \& Al- } \\
\text { Abed, } 2008 \\
\text { (14) } \\
\text { (CS) }\end{array}$ & KSA & Permanent & 1115 & $\begin{array}{l}10-14 \text { y } \\
(M)\end{array}$ & School & WHO & $\begin{array}{l}\text { Stepwise } \\
\text { logistic } \\
\text { regression }\end{array}$ & $\mathrm{DCP}=68.9 \%$ \\
\hline $\begin{array}{l}\text { Nationality } \\
\text { (Emirati) }\end{array}$ & + & $\begin{array}{l}\text { Elamin et al. } \\
2018(13) \\
(\mathrm{CS})\end{array}$ & UAE & Primary & 186 & $\begin{array}{l}1.5-4 y \\
(M, F)\end{array}$ & School & $\begin{array}{l}\text { WHO } \\
\text { (dmft) }\end{array}$ & $\begin{array}{l}\text { T-tests, } \\
\text { Pearson's }\end{array}$ & $\begin{array}{l}\mathrm{DCP}=41 \% \\
\mathrm{dmft}=1.7(\mathrm{SD} \\
2.81)\end{array}$ \\
\hline $\begin{array}{l}\text { Geographical } \\
\text { Location }\end{array}$ & Varied $^{j}$ & $\begin{array}{l}\text { Al Mutawa et } \\
\text { al. } 2010(32) \\
\text { (CS) }\end{array}$ & Kuwait & Primary & 1277 & $\begin{array}{l}4 \& 5 y \\
(M, F)\end{array}$ & School & WHO & $\begin{array}{l}\text { T-test } \\
\text { Chi Square }\end{array}$ & $\begin{array}{l}\mathrm{dft} / \mathrm{dfs}=3.7 / 6 \\
(4 \mathrm{y}) \\
\mathrm{dft} / \mathrm{dfs}=4.8 / 9 \\
(5 \mathrm{y})\end{array}$ \\
\hline $\begin{array}{l}\text { Geographical } \\
\text { Location }\end{array}$ & Varied $^{\mathrm{k}}$ & $\begin{array}{l}\text { Ballouk \& } \\
\text { Dashash } \\
2019 \\
(33) \\
\text { (CS) }\end{array}$ & Syria & $\begin{array}{l}\text { Primary } \\
\text { Permanent }\end{array}$ & 1500 & $\begin{array}{l}8-12 y \\
(M, F)\end{array}$ & School & $\begin{array}{l}\text { WHO } \\
\text { (DMFT, } \\
\text { dmft) }\end{array}$ & $\begin{array}{l}\text { ANOVA } \\
\text { Chi-Square }\end{array}$ & $\begin{array}{l}\mathrm{DCP}=79.1 \% \\
\mathrm{dmft}=2.47(\mathrm{~S} C \\
2.94) \\
\text { DMFT }=2.03 \\
(\mathrm{SD} \mathrm{1.81)}\end{array}$ \\
\hline Rural living & + & $\begin{array}{l}\text { Al- } \\
\text { Mendalawi \& } \\
\text { Karam, } 2014 \\
(26) \\
(\mathrm{CC})\end{array}$ & Iraq & Primary & 684 & $\begin{array}{l}<6 y \\
(M, F)\end{array}$ & Clinic & $\begin{array}{l}\text { WHO } \\
(\mathrm{DMFT})^{\mathrm{e}}\end{array}$ & Chi-Square & $\mathrm{DMFT}=2.03$ \\
\hline Rural living & + & $\begin{array}{l}\text { Elamin et al. } \\
2018(13) \\
(\mathrm{CS})\end{array}$ & UAE & Primary & 186 & $\begin{array}{l}1.5-4 y \\
(M, F)\end{array}$ & School & $\begin{array}{l}\text { WHO } \\
\text { (dmft) }\end{array}$ & $\begin{array}{l}\text { T-test, } \\
\text {-Pearson's }\end{array}$ & $\begin{array}{l}\mathrm{DCP}=41 \% \\
\mathrm{Dmft}=1.7(\mathrm{SD} \\
2.81)\end{array}$ \\
\hline Urban living & + & $\begin{array}{l}\text { Bayat- } \\
\text { Movahed et } \\
\text { al. } 2011 \text { (18) } \\
\text { (CS) }\end{array}$ & Iran & $\begin{array}{l}\text { Primary } \\
\text { Permanent }\end{array}$ & 18946 & $\begin{array}{l}3,6,9,12 y \\
(M, F)\end{array}$ & $\begin{array}{l}\text { Community } \\
\text { health } \\
\text { centres }\end{array}$ & WHO & $\begin{array}{l}\text { T-test } \\
\text { Z-test }\end{array}$ & $\begin{array}{l}\mathrm{dmft}=1.9(3 \mathrm{y}) \\
\mathrm{dmft}=5.0(6 \mathrm{y}) \\
\mathrm{dmft}=3.6(9 \mathrm{y}) \\
\mathrm{dmft}=0.6(12 \mathrm{y} \\
\text { DMFT=0.2(6y } \\
\text { DMFT }=0.9(9 \mathrm{y} \\
\text { DMFT }=1.9 \\
(12 \mathrm{y})\end{array}$ \\
\hline $\begin{array}{l}\text { Semi-urban } \\
\text { living }\end{array}$ & + & $\begin{array}{l}\text { Al Darwish et } \\
\text { al. } 2014 \text { (34) } \\
\text { (CS) }\end{array}$ & Qatar & Permanent & 2113 & $\begin{array}{l}12-14 \text { y } \\
(M, F)\end{array}$ & School & $\begin{array}{l}\text { WHO } \\
\text { (DMFT) }\end{array}$ & $\begin{array}{l}\text { Multinomial } \\
\text { logistic } \\
\text { regression, } \\
\text { Adjusted } \\
\text { Odds Ratio }\end{array}$ & $\begin{array}{l}\text { DCP }=85 \% \\
\text { DMFT (12 y) } \\
=4.62(\text { SD 3.2) } \\
\text { DMFT (13 y) } \\
=4.79(\text { SD 3.5) } \\
\text { DMFT (14 y) } \\
=5.51(\text { SD 3.7) }\end{array}$ \\
\hline School type & & & & & & & & & & \\
\hline $\begin{array}{l}\text { Public } \\
\text { Schools }\end{array}$ & + & $\begin{array}{l}\text { Farsi \& } \\
\text { Elkhodary } \\
2017 \text { (35) } \\
\text { (CS) }\end{array}$ & KSA & Permanent & 801 & $\begin{array}{l}\text { Mean } \\
\text { age }=16.5 \\
y \\
\text { (Grade } \\
11) \\
(\mathrm{M}, \mathrm{F})\end{array}$ & School & $\begin{array}{l}\text { ASTDD } \\
\text { (DT) }\end{array}$ & $\begin{array}{l}\text { Mann- } \\
\text { Whitney }\end{array}$ & $\begin{array}{l}\text { DT boys=3.9 } \\
(\text { SD 3.5) } \\
\text { DT girls=4.9 } \\
\text { (SD 3.7) }\end{array}$ \\
\hline $\begin{array}{l}\text { Public } \\
\text { Schools }\end{array}$ & + & $\begin{array}{l}\text { Al-Malik et al. } \\
2002(9) \\
(\mathrm{CS})\end{array}$ & KSA & Primary & 987 & $\begin{array}{l}2-5 y \\
(M, F)\end{array}$ & School & $\begin{array}{l}\text { BASCD } \\
\text { (dmft, } \\
\text { dmfs) }\end{array}$ & $\begin{array}{l}\text { Stepwise } \\
\text { multiple } \\
\text { logistic } \\
\text { regression }\end{array}$ & $\begin{array}{l}\text { DCP }=73 \% \\
\text { Rampant } \\
\text { caries }=43 \% \\
\text { dmft }=4.8 \\
\text { dmfs }=12.7\end{array}$ \\
\hline
\end{tabular}




\begin{tabular}{|c|c|c|c|c|c|c|c|c|c|c|}
\hline $\begin{array}{l}\text { Private } \\
\text { schools }\end{array}$ & - & $\begin{array}{l}\text { Sgan-Cohen } \\
\text { et al. } 2015 \\
\text { (36) } \\
\text { (CS) }\end{array}$ & Palestine & Permanent & 286 & $\begin{array}{l}12 y \\
(M, F)\end{array}$ & School & $\begin{array}{l}\text { WHO } \\
\text { (DMFT) }\end{array}$ & $\begin{array}{l}\text { Multivariate } \\
\text { analysis }\end{array}$ & DMFT =1.98 \\
\hline $\begin{array}{l}\text { Public } \\
\text { schools }\end{array}$ & + & $\begin{array}{l}\text { Cinar \& } \\
\text { Murtomaa, } \\
2011 \text { (37) } \\
\text { (CS) }\end{array}$ & Turkey & Permanent & 611 & $\begin{array}{l}10-12 \text { y } \\
(M, F)\end{array}$ & School & $\begin{array}{l}\text { WHO } \\
\text { (DMFS) }\end{array}$ & $\begin{array}{l}\text { T-test } \\
\text { Chi-Square } \\
\text { Logistic } \\
\text { regression }\end{array}$ & $\begin{array}{l}\text { DMFS=4.44 } \\
\text { (public school' } \\
\text { DMFS=2.64 } \\
\text { (private schoo }\end{array}$ \\
\hline $\begin{array}{l}\text { Public } \\
\text { schools }\end{array}$ & + & $\begin{array}{l}\text { Cinar \& } \\
\text { Murtromaa, } \\
2008 \text { (38) } \\
\text { (CS) }\end{array}$ & Turkey' & Permanent & 611 & $\begin{array}{l}10-12 \text { y } \\
(M, F)\end{array}$ & School & $\begin{array}{l}\text { WHO } \\
\text { (DMFT) }\end{array}$ & $\begin{array}{l}\text { T-test } \\
\text { Logistic } \\
\text { regression }\end{array}$ & $\mathrm{DMFT}=2.93$ \\
\hline
\end{tabular}

$A A P D$ American Association Paediatric Dentistry, BASCD British Association for the Study of Community Dentistry, CS Cross-sectional, CC Case control, DCP Dental caries prevalence, deft decayed, extracted due to caries and filled primary teeth, $d f s$ decayed, filled surfaces in primary teeth, $d f t$ decayed, filled primary teeth, $d m f s$ decayed, missing and filled surfaces in primary teeth; DMFS decayed, missing and filled surfaces in permanent teeth, dmft decayed, missing, filled primary teeth, DMFT decayed, missing, filled permanent teeth, ECC Early childhood caries, ECCP Early childhood caries prevalence, $F$ Female, ICADS The international caries Detection and Assessment System, $L$ Longitudinal, KSA Kingdom of Saudi Arabia, $m$ months $M$ Male, WHO World Health Organisation, SiC Significant caries index, SD Standard deviation, $y$ years

aThe CAST index scoring system is as follows: "0: sound", "1: sealant", "2: restoration”, "3: enamel lesions", "4, 5: dentine lesions", "6: pulp involvement", "7: abscess/fistula", "8: tooth loss". If a situation did not match any codes from 0 to 8 , a code 9 was assigned. The codes $0-2,3,4-5,6-7$, and 8 were considered as "healthy", "pre-morbidity", "morbidity", "serious morbidity", and "mortality", respectively

${ }^{\mathrm{b}}$ The authors describe their scoring as WHO (DMFT) whereas it should be noted that the age group is 3-6 year olds where normally WHO (dmft) is being used.

${ }^{\mathrm{C}}$ Data was collected during 9 years. In each year data was collected in a new sample.

${ }^{\mathrm{d}}$ The mean FT score was significantly higher for children having mothers with higher education, fathers with higher education and for residents of higher socio-economic areas, as compared to their counterparts in the opposite groups.

${ }^{\mathrm{e}}$ The authors describe their scoring as WHO(DMFT) whereas it should be noted that the age group is 0-6 year olds where normally WHO (dmft) is being used.

fThe SES level was based on the level of parental education and its type, guardians' occupation and address.

gSES score based on parental education and suburban location of residence.

${ }^{\text {h}}$ SES score based on school type: low SES: deprived areas and refugee camps, medium SES: state schools, high SES: private schools

'The sibling order impacts dental caries status: $84.44 \%, 74,37 \%, 40.19 \%$ and $77.65 \%$ of only, eldest, middle and youngest child/ren had dental caries, respectively.

jDental caries prevalence differed between the 6 different regions/governorates in Kuwait but the characteristics of the regions are not described.

${ }^{k}$ Dental caries prevalence differed between different parts/regions in Damascus but the characteristics of the regions are not described

'A comparative study with Finland.

Table 4 Statistically significant dental related determinants/risk factors contributing to dental caries 


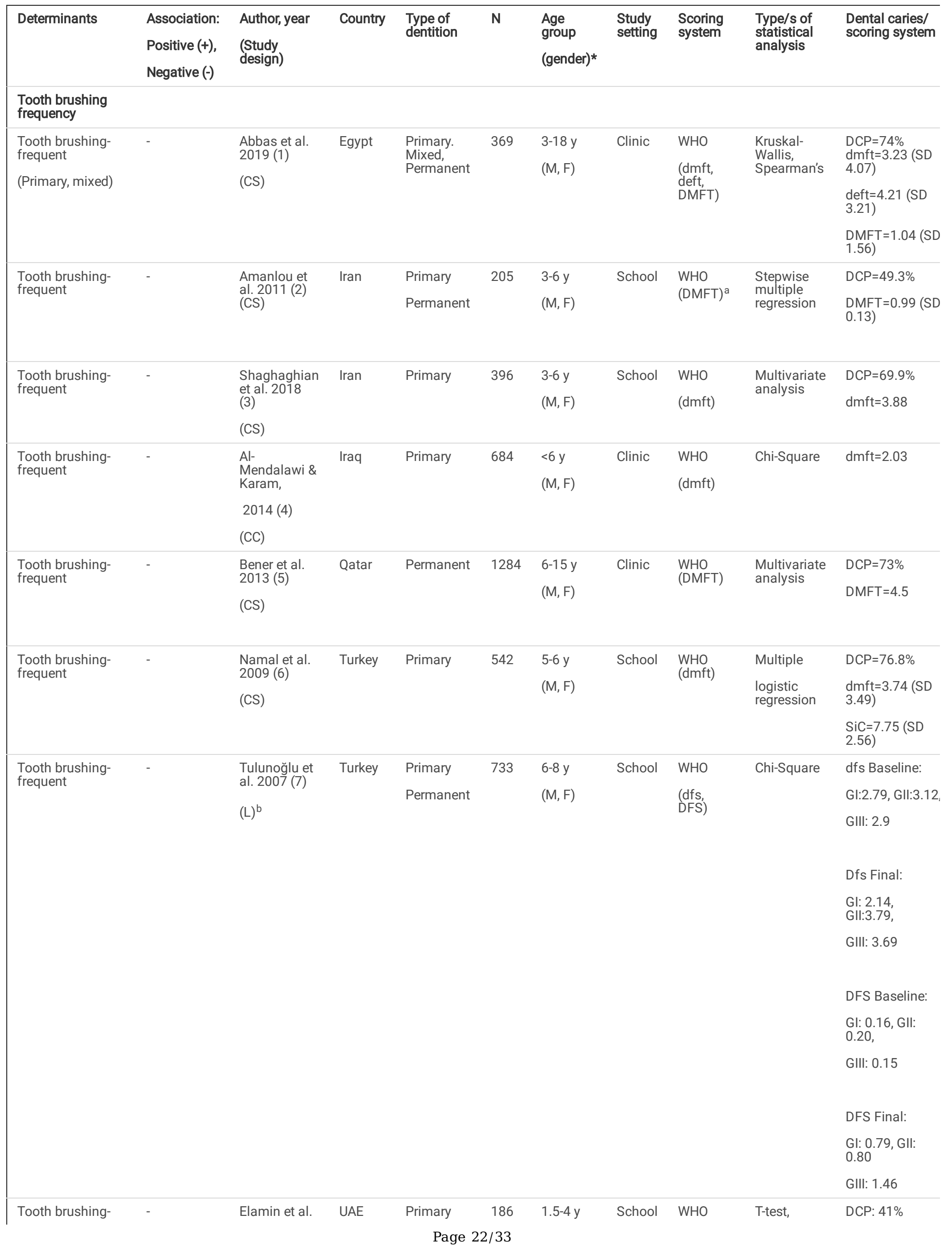




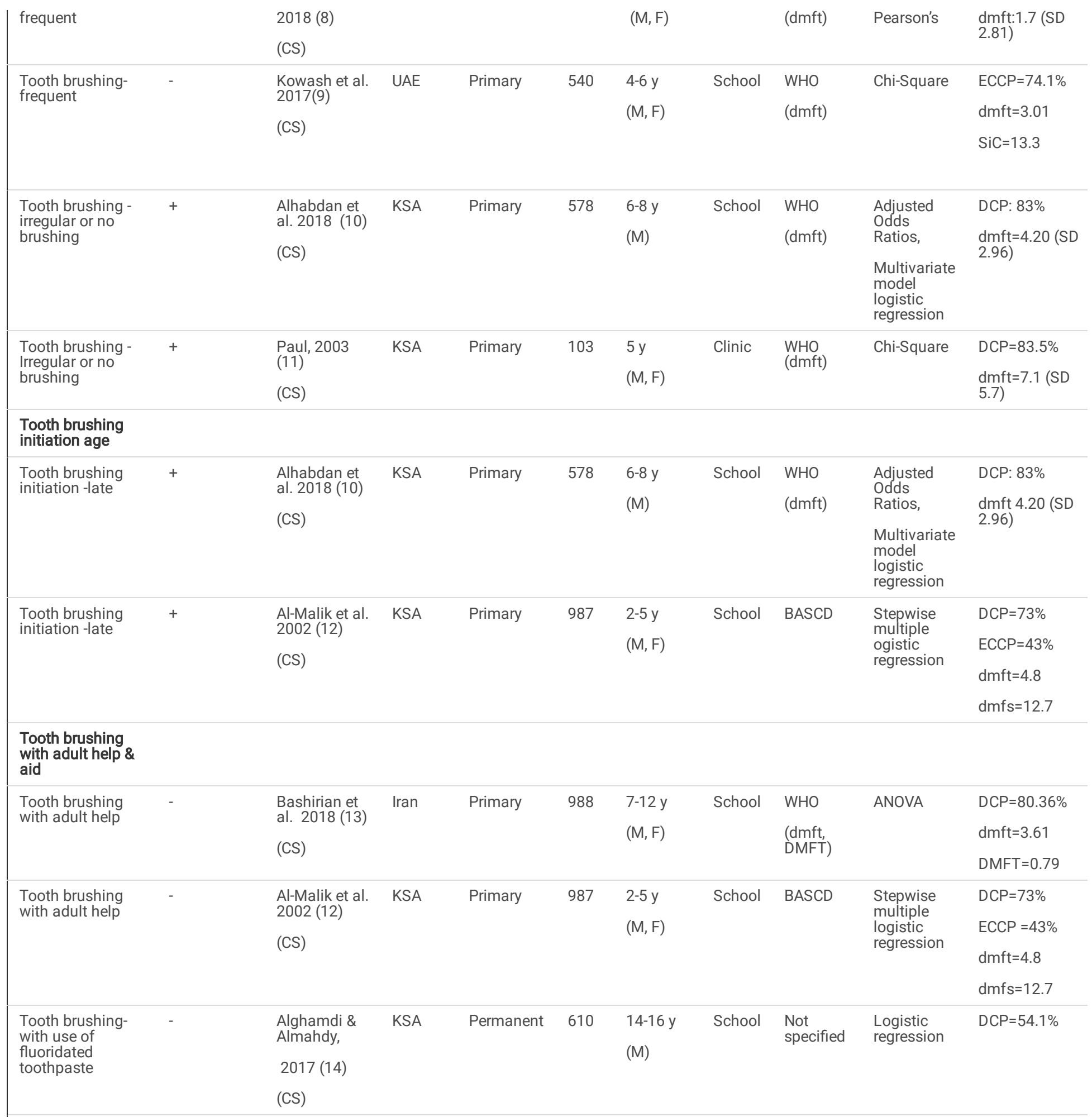

\section{Oral hygiene and}

practices

attributes

Oral hygiene ${ }^{c}$

(CAST score of

$\geq 3$ in primary

molar teeth)
Babaei et al. Ira 2019 (15)

(CS)

\begin{tabular}{|c|c|}
\hline $\begin{array}{l}\text { Primary \& } \\
\text { Permanent }\end{array}$ & 739 \\
\hline $\begin{array}{l}\text { molar } \\
\text { teeth }\end{array}$ & \\
\hline
\end{tabular}

\section{CAST \\ index ${ }^{d}$ \\ $\begin{array}{ll}\text { Multivariate } & \text { Permanent } \\ \text { logistic } & \text { molars: } \\ \text { regression } & \\ & \text { Healthy status }\end{array}$}

in

$89.3-93.7 \%$ of the teeth.

Primary molars:

Morbidity status in 25.3 to $31.2 \%$ of the teeth 


\begin{tabular}{|c|c|c|c|c|c|c|c|c|c|c|}
\hline & & & & & & & & & & $\begin{array}{l}\text { Serious } \\
\text { morbidity status } \\
\text { with }\end{array}$ \\
\hline & & & & & & & & & & $\begin{array}{l}\text { Pulp } \\
\text { involvement in } \\
2.9-10.5 \% \text { of } \\
\text { the teeth and } \\
\text { abscess/fistula } \\
\text { in }\end{array}$ \\
\hline & & & & & & & & & & $<1 \%$ of the teeth \\
\hline \multirow{10}{*}{$\begin{array}{l}\text { Oral Hygiene- } \\
\text { dental plaque } \\
\text { presence }\end{array}$} & \multirow[t]{10}{*}{+} & $\begin{array}{l}\text { Mohebbi et } \\
\text { al. }\end{array}$ & \multirow[t]{10}{*}{ Iran } & \multirow[t]{10}{*}{ Primary } & \multirow[t]{10}{*}{504} & \multirow{10}{*}{$\begin{array}{l}12-36 \\
\mathrm{mo} \\
(\mathrm{M}, \mathrm{F})\end{array}$} & \multirow[t]{10}{*}{ Clinic } & \multirow{10}{*}{$\begin{array}{l}\text { WHO } \\
(\mathrm{dmft})\end{array}$} & \multirow{10}{*}{$\begin{array}{l}\text { Logistic } \\
\text { regression }\end{array}$} & ECCP: \\
\hline & & \multirow{9}{*}{$\begin{array}{l}2006(16) \\
(C S)\end{array}$} & & & & & & & & $12-15$ mo=3\% \\
\hline & & & & & & & & & & $16-19 \mathrm{mo}=9 \%$ \\
\hline & & & & & & & & & & $20-25 \mathrm{mo}=14 \%$ \\
\hline & & & & & & & & & & $26-36 \mathrm{mo}=33 \%$ \\
\hline & & & & & & & & & & $\mathrm{dmft}=$ \\
\hline & & & & & & & & & & $<0.1(12-15 \mathrm{mo})$ \\
\hline & & & & & & & & & & $\begin{array}{l}\mathrm{dmft}=0.2(16-19 \\
\mathrm{mo})\end{array}$ \\
\hline & & & & & & & & & & $\begin{array}{l}\mathrm{dmft}=0.4(20-25 \\
\mathrm{mo})\end{array}$ \\
\hline & & & & & & & & & & $\begin{array}{l}\mathrm{dmft}=1.2(26-36 \\
\mathrm{mo})\end{array}$ \\
\hline \multirow[t]{7}{*}{ Oral hygiene-poor } & \multirow[t]{7}{*}{+} & \multirow{7}{*}{$\begin{array}{l}\text { Al-Mutawa el } \\
\text { al. } 2006 \text { (17) } \\
\text { (CS) }\end{array}$} & \multirow[t]{7}{*}{ Kuwait } & \multirow{7}{*}{$\begin{array}{l}\text { Primary } \\
\text { Permanent }\end{array}$} & \multirow[t]{7}{*}{4588} & \multirow{7}{*}{$\begin{array}{l}5,6,12,14 \\
y \\
(M, F)\end{array}$} & \multirow[t]{7}{*}{ School } & \multirow{7}{*}{$\begin{array}{l}\text { WHO } \\
\text { (dft, } \\
\text { DMFT, } \\
\text { DFS) }\end{array}$} & \multirow{7}{*}{$\begin{array}{l}\text { Multivariate } \\
\text { analysis }\end{array}$} & $\mathrm{dft}=4.6(5-6 \mathrm{y})$ \\
\hline & & & & & & & & & & DMFT $=0.4(6 \mathrm{y})$ \\
\hline & & & & & & & & & & DMFT =2.6 (12y', \\
\hline & & & & & & & & & & $\begin{array}{l}\text { DMFT=3.9 (14 } \\
\text { y) }\end{array}$ \\
\hline & & & & & & & & & & DFS=0.4 (6y) \\
\hline & & & & & & & & & & $\mathrm{DFS}=3.4(12 \mathrm{y})$ \\
\hline & & & & & & & & & & DFS=5.2 (14 y) \\
\hline \multirow[t]{2}{*}{ Oral hygiene-poor } & \multirow[t]{2}{*}{+} & $\begin{array}{l}\text { Amin \& Al- } \\
\text { Abad, } 2008 \\
\text { (18) }\end{array}$ & \multirow[t]{2}{*}{ KSA } & \multirow[t]{2}{*}{ Permanent } & 1115 & $\begin{array}{l}10-14 \text { y } \\
(M)\end{array}$ & School & WHO & $\begin{array}{l}\text { Stepwise } \\
\text { logistic } \\
\text { regression }\end{array}$ & $\mathrm{DCP}=68.9 \%$ \\
\hline & & (CS) & & & & & & & & \\
\hline Oral hygiene-poor & + & $\begin{array}{l}\text { Dashash \& } \\
\text { Blinkhorn, } \\
2012 \text { (19) }\end{array}$ & Syria & Primary & 727 & $\begin{array}{l}5 y \\
(M, F)\end{array}$ & School & $\begin{array}{l}\text { WHO } \\
\text { (dmft, } \\
\text { DMFT) }\end{array}$ & $\begin{array}{l}\text { Multiple } \\
\text { logistic } \\
\text { regression }\end{array}$ & $\begin{array}{l}\mathrm{DCP}=61 \% \\
\mathrm{dmft}=3.27(3.71,\end{array}$ \\
\hline & & (CS) & & & & & & & & \\
\hline Oral hygiene-poor & + & $\begin{array}{l}\text { Jaghasi et al. } \\
2012(20)\end{array}$ & Syria & $\begin{array}{l}\text { Not } \\
\text { specified }\end{array}$ & 504 & $6-12 y$ & School & WHO & $\begin{array}{l}\text { Logistic } \\
\text { regression }\end{array}$ & $\mathrm{DCP}=85 \%$ \\
\hline & & (CS) & & & & $(\mathrm{M}, \mathrm{F})$ & & & & \\
\hline $\begin{array}{l}\text { Oral practices- } \\
\text { poor }\end{array}$ & + & $\begin{array}{l}\text { Kowash et al. } \\
2017(9)\end{array}$ & UAE & Primary & 540 & $4-6 y$ & School & WHO & Chi-Square & $\mathrm{ECCP}=74.1 \%$ \\
\hline & & & & & & $(\mathrm{M}, \mathrm{F})$ & & $(\mathrm{dmft})$ & & $\mathrm{dmft}=3.01$ \\
\hline & & & & & & & & & & $\mathrm{SiC}=13.3$ \\
\hline $\begin{array}{l}\text { Not feeling } \\
\text { embarrassed }\end{array}$ & - & $\begin{array}{l}\text { Ahmed et al. } \\
2007(21)\end{array}$ & Iraq & Permanent & 392 & $12 \mathrm{y}$ & School & WHO & ANOVA & $\mathrm{DCP}=62 \%$ \\
\hline when smiling & & (CS) & & & & $(\mathrm{M}, \mathrm{F})$ & & (DMFT) & & DMFT=1.7 \\
\hline $\begin{array}{l}\text { Permanent } \\
\text { dentition }\end{array}$ & + & $\begin{array}{l}\text { Al-Mutawa el } \\
\text { al. } 2006(17)\end{array}$ & Kuwait & Primary & 4588 & $\begin{array}{l}5,6,12,14 \\
y\end{array}$ & School & WHO & $\begin{array}{l}\text { Multivariate } \\
\text { analysis }\end{array}$ & $\mathrm{dft}=4.6(5-6 \mathrm{y})$ \\
\hline & & & & Permanent & & & & $\begin{array}{l}\text { (dft, } \\
\text { DMFT }\end{array}$ & & DMFT $=0.4(6 y)$ \\
\hline & & & & & & & & DFS) & & DMFT=2.6 (12y', \\
\hline & & & & & & & & & & DMFT-3.9 (14 y) \\
\hline & & & & & & & & & & DFS=0.4 (6 y) \\
\hline
\end{tabular}




\section{Dental services}

visits attributes

\begin{tabular}{|c|c|c|c|c|c|c|c|c|c|c|}
\hline $\begin{array}{l}\text { Dental services - } \\
\text { child's first visit }\end{array}$ & - & $\begin{array}{l}\text { Kabil \& } \\
\text { Eltawil, } \\
2017 \text { (22) } \\
\text { (CS) }\end{array}$ & Egypt & Primary & 108 & $\begin{array}{l}2-4 y \\
(M, F)\end{array}$ & Clinic & WHO & $\begin{array}{l}\text { Logistic } \\
\text { regression }\end{array}$ & $\begin{array}{l}E C C P=57 \%(2-3 \\
\text { y) ECCP }=73 \% \\
(3-4 \text { y) }\end{array}$ \\
\hline $\begin{array}{l}\text { Dental visits- } \\
\text { regular }\end{array}$ & - & $\begin{array}{l}\text { Kabil and } \\
\text { Eltawil, } 2016 \\
\text { (23) } \\
\text { (CS) }\end{array}$ & Egypt & Primary & 140 & $\begin{array}{l}2-4 y \\
(M, F)\end{array}$ & Clinic & $\begin{array}{l}\text { WHO } \\
\text { AAPD- } \\
\text { ECC }\end{array}$ & $\begin{array}{l}\text { Logistic } \\
\text { regression }\end{array}$ & $\mathrm{DMFT}=9.96$ \\
\hline $\begin{array}{l}\text { Dental visits- } \\
\text { regular }\end{array}$ & - & $\begin{array}{l}\text { Alhumaid et } \\
\text { al. } 2018 \text { (24) } \\
\text { (CS) }\end{array}$ & KSA & $\begin{array}{l}\text { Primary } \\
\text { Permanent }\end{array}$ & 921 & $\begin{array}{l}6-12 y \\
(M, F)\end{array}$ & School & $\begin{array}{l}\text { Basic } \\
\text { screening } \\
\text { survey }\end{array}$ & $\begin{array}{l}\text { Multivariate } \\
\text { analysis }\end{array}$ & $\mathrm{DCP}=63.5 \%$ \\
\hline $\begin{array}{l}\text { Dental services - } \\
\text { not attending for } \\
\text { preventive } \\
\text { measures }\end{array}$ & + & $\begin{array}{l}\text { Dashash \& } \\
\text { Blinkhorn, } \\
2012(19) \\
\text { (CS) }\end{array}$ & Syria & Primary & 727 & $\begin{array}{l}5 y \\
(M, F)\end{array}$ & School & $\begin{array}{l}\text { WHO } \\
\text { (dmft, } \\
\text { DMFT) }\end{array}$ & $\begin{array}{l}\text { Multiple } \\
\text { logistic } \\
\text { regression }\end{array}$ & $\begin{array}{l}\mathrm{DCP}=61 \% \\
\mathrm{dmft}=3.27(\mathrm{SD} \\
3.71)\end{array}$ \\
\hline $\begin{array}{l}\text { Dental visits- for } \\
\text { pain } \\
\text { complaints/dental } \\
\text { problems }\end{array}$ & + & $\begin{array}{l}\text { Shaghaghian } \\
\text { et al. } 2018 \\
\text { (3) } \\
\text { (CS) }\end{array}$ & Iran & Primary & 396 & $\begin{array}{l}3-6 y \\
(M, F)\end{array}$ & School & WHO & $\begin{array}{l}\text { Multivariate } \\
\text { analysis }\end{array}$ & $\begin{array}{l}\mathrm{DCP}=69.9 \% \\
\mathrm{dmft}=3.88\end{array}$ \\
\hline $\begin{array}{l}\text { Dental visits- for } \\
\text { pain } \\
\text { complaints/dental } \\
\text { problems }\end{array}$ & + & $\begin{array}{l}\text { Alhabdan et } \\
\text { al. } 2018 \text { (10) } \\
\text { (CS) }\end{array}$ & KSA & Primary & 578 & $\begin{array}{l}6-8 y \\
(M)\end{array}$ & School & $\begin{array}{l}\text { WHO } \\
\text { (dmft) }\end{array}$ & $\begin{array}{l}\text { Adjusted } \\
\text { Odds } \\
\text { Ratios, } \\
\text { Multivariate } \\
\text { model } \\
\text { logistic } \\
\text { regression }\end{array}$ & $\begin{array}{l}\text { DCP: } 83 \% \\
d m f t=4.20(S D \\
2.96)\end{array}$ \\
\hline Dental visits & Unclear & $\begin{array}{l}\text { Khadri et al. } \\
2018 \text { (25) } \\
\text { (CS) }\end{array}$ & UAE & Permanent & 803 & $\begin{array}{l}11-17 y \\
(M, F)\end{array}$ & School & $\begin{array}{l}\text { WHO } \\
\text { (DMFT) }\end{array}$ & $\begin{array}{l}\text { Multivariate } \\
\text { regression }\end{array}$ & $\begin{array}{l}\mathrm{DCP}=75 \% \\
\mathrm{DMFT}=3.19(\mathrm{SD} \\
2.9)\end{array}$ \\
\hline
\end{tabular}

\section{Parental oral \\ health status and \\ knowledge \\ attributes}

\begin{tabular}{|c|c|c|c|c|c|c|c|c|c|c|}
\hline $\begin{array}{l}\text { Parental dental } \\
\text { caries status }\end{array}$ & + & $\begin{array}{l}\text { Yazdan et al. } \\
2018(26) \\
\text { (CS) }\end{array}$ & Iran & $\begin{array}{l}\text { Primary } \\
\text { Permanent }\end{array}$ & 258 & $\begin{array}{l}5-15 y \\
(M, F)\end{array}$ & Clinic & $\begin{array}{l}\text { WHO } \\
\text { (dmft, } \\
\text { DMFT) }\end{array}$ & Pearson's & $\begin{array}{l}\mathrm{dmft}=6.33 \\
(\mathrm{SD} 3.80) \\
\\
\text { DMFT }=1.48 \\
(\mathrm{SD} 1.90)\end{array}$ \\
\hline $\begin{array}{l}\text { Parental } \\
\text { knowledge on oral } \\
\text { hygiene }\end{array}$ & - & $\begin{array}{l}\text { Yazdan et al. } \\
2018(26) \\
(\mathrm{CS})\end{array}$ & Iran & $\begin{array}{l}\text { Primary } \\
\text { Permanent }\end{array}$ & 258 & $\begin{array}{l}5-15 y \\
(M, F)\end{array}$ & Clinic & $\begin{array}{l}\text { WHO } \\
\text { (dmft, } \\
\text { DMFT) }\end{array}$ & Pearson's & $\begin{array}{l}\mathrm{dmft}=6.33 \\
(\mathrm{SD} 3.80) \\
\\
\text { DMFT }=1.48 \\
(\mathrm{SD} 1.90)\end{array}$ \\
\hline $\begin{array}{l}\text { Mother's caries } \\
\text { experience }\end{array}$ & + & $\begin{array}{l}\text { Kabil \& } \\
\text { Eltawil, } 2016 \\
\text { (23) } \\
\text { (CS) }\end{array}$ & Egypt & Primary & 140 & $\begin{array}{l}2-4 y \\
(M, F)\end{array}$ & Clinic & $\begin{array}{l}\text { WHO } \\
\text { (DMFT) } \\
\text { AAPD }\end{array}$ & $\begin{array}{l}\text { Logistic } \\
\text { regression }\end{array}$ & $\mathrm{DMFT}=9.96$ \\
\hline $\begin{array}{l}\text { Mother's current } \\
\text { caries experience }\end{array}$ & + & $\begin{array}{l}\text { Kabil \& } \\
\text { Eltawil, } \\
2017 \text { (22) } \\
\text { (CS) }\end{array}$ & Egypt & Primary & 108 & $\begin{array}{l}2-4 y \\
(M, F)\end{array}$ & Clinic & WHO & $\begin{array}{l}\text { Logistic } \\
\text { regression }\end{array}$ & $\begin{array}{l}\text { ECCP }=57 \%(2- \\
3 y r s), 73 \%(3- \\
4 y r s)\end{array}$ \\
\hline $\begin{array}{l}\text { Parental } \\
\text { knowledge on oral } \\
\text { hygiene }\end{array}$ & - & $\begin{array}{l}\text { Kowash et al. } \\
2017(9) \\
\text { (CS) }\end{array}$ & UAE & Primary & 540 & $\begin{array}{l}4-6 y \\
(M, F)\end{array}$ & School & $\begin{array}{l}\text { WHO } \\
\text { (dmft) }\end{array}$ & Chi-Square & $\begin{array}{l}\text { ECCP }=74.1 \% \\
d m f t=3.01 \\
\text { SiC }=13.3\end{array}$ \\
\hline
\end{tabular}


AAPD American Association Paediatric Dentistry, BASCD British Association for the Study of Community Dentistry, CS Cross-sectional, CC Case control, DCP Dental caries prevalence, deft decayed, extracted due to caries and filled primary teeth, $d f s$ decayed, filled surfaces in primary teeth, $d f t$ decayed, filled primary teeth, dmfs decayed, missing and filled surfaces in primary teeth; DMFS decayed, missing and filled surfaces in permanent teeth;

$d m f t$ decayed, missing, filled primary teeth, DMFT decayed, missing, filled permanent teeth, ECC Early childhood caries, ECCP Early childhood caries prevalence, FFemale, ICADS The international caries Detection and Assessment System, L Longitudinal, KSA Kingdom of Saudi Arabia, $m$ months $M$ Male, WHO World Health Organisation, SiC Significant caries index, SD Standard deviation, $y$ years

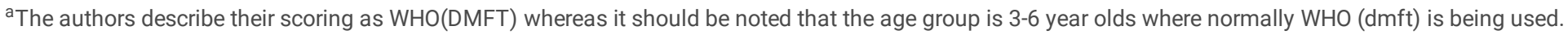

${ }^{b}$ Based on the baseline assessment the participants were categorized into; Group I having sufficient oral health behaviours, Group II having moderate oral health behaviours and Group III having insufficient oral health behaviours and then the participants were followed for a 2-year period.

${ }^{\mathrm{c} O r a l}$ hygiene measured by Oral Health index-Simplified (OHI-S)

${ }^{\mathrm{d}}$ The CAST index scoring system is as follows: "0: sound", "1: sealant”, "2: restoration”, "3: enamel lesions", "4, 5: dentine lesions", "6: pulp involvement", "7: abscess/fistula", "8: tooth loss". If a situation did not match any codes from 0 to 8 , a code 9 was assigned. The codes $0-2,3,4-5,6-7$, and 8 were considered as "healthy", "pre-morbidity", "morbidity", "serious morbidity", and "mortality", respectively

Table 5 Statistically significant nutrition-related determinants contributing to dental caries 


\begin{tabular}{|c|c|c|c|c|c|c|c|c|c|c|}
\hline Determinants & $\begin{array}{l}\text { Association: } \\
\text { Positive (+), } \\
\text { Negative (-) }\end{array}$ & $\begin{array}{l}\text { Author } \\
\text { (Study } \\
\text { design) }\end{array}$ & Country & $\begin{array}{l}\text { Type of } \\
\text { dentition }\end{array}$ & $\mathbf{N}$ & $\begin{array}{l}\text { Age } \\
\text { group } \\
\text { (Gender) }\end{array}$ & $\begin{array}{l}\text { Study } \\
\text { setting }\end{array}$ & $\begin{array}{l}\text { Scoring } \\
\text { system }\end{array}$ & $\begin{array}{l}\text { Type/s of } \\
\text { statistical } \\
\text { analysis }\end{array}$ & $\begin{array}{l}\text { Dental } \\
\text { caries/ } \\
\text { scoring } \\
\text { results }\end{array}$ \\
\hline \multicolumn{11}{|l|}{ Beverages } \\
\hline Soft drinks & + & $\begin{array}{l}\text { Chedid et } \\
\text { al. } 2011 \\
\text { (1) } \\
\text { (CS) }\end{array}$ & Lebanon & Primary & 99 & $\begin{array}{l}2-4 y \\
(M, F)\end{array}$ & Clinic & $\begin{array}{l}\text { WHO } \\
\text { (DFS score } \\
\text { and bite } \\
\text { wing } \\
\text { radiographs) }\end{array}$ & Pearson's & $\mathrm{DCP}=74.7 \%$ \\
\hline Soft drinks & + & $\begin{array}{l}\text { Alhabdan } \\
\text { et al. } \\
2018 \text { (2) } \\
\text { (CS) }\end{array}$ & KSA & Primary & 578 & $\begin{array}{l}6-8 y \\
(M)\end{array}$ & School & $\begin{array}{l}\text { WHO } \\
(\mathrm{dmft})\end{array}$ & $\begin{array}{l}\text { Adjusted Odds } \\
\text { Ratios, } \\
\text { Multivariate } \\
\text { model logistic } \\
\text { regression }\end{array}$ & $\begin{array}{l}\text { DCCP: } 83 \% \\
\mathrm{dmft}=4.20 \\
\text { (SD 2.96) }\end{array}$ \\
\hline Soft drinks & + & $\begin{array}{l}\text { Hashim } \\
\text { et al. } \\
2009^{a}(3) \\
\text { (CS) }\end{array}$ & UAE & Primary & 1036 & $\begin{array}{l}5-6 y \\
(M, F)\end{array}$ & School & $\begin{array}{l}\text { WHO } \\
\text { (dmft) }\end{array}$ & $\begin{array}{l}\text { Adjusted Risk } \\
\text { Ratio, } \\
\text { Bivariate } \\
\text { analysis }\end{array}$ & $\mathrm{dmft}=4.5$ \\
\hline $\begin{array}{l}\text { Fruit juice- } \\
\text { before bed }\end{array}$ & + & $\begin{array}{l}\text { Al-Malik } \\
\text { et al. } \\
2002 \text { (4) } \\
\text { (CS) }\end{array}$ & KSA & Primary & 987 & $\begin{array}{l}2-5 y \\
(M, F)\end{array}$ & School & BASCD & $\begin{array}{l}\text { Stepwise } \\
\text { multiple } \\
\text { logistic } \\
\text { regression }\end{array}$ & $\begin{array}{l}\mathrm{DCP}=73 \% \\
\text { Rampant } \\
\text { caries=43\% } \\
\mathrm{dmft}=4.8 \\
\mathrm{dmfs}=12.7\end{array}$ \\
\hline $\begin{array}{l}\text { Fruit juice- } \\
\text { frequent } \\
\text { consumption }\end{array}$ & + & $\begin{array}{l}\text { Hashim } \\
\text { et al. } \\
2009^{a}(3) \\
\text { (CS) }\end{array}$ & UAE & Primary & 1036 & $\begin{array}{l}5-6 y \\
(M, F)\end{array}$ & School & WHO & $\begin{array}{l}\text { Risk Ratio, } \\
\text { Bivariate } \\
\text { analysis }\end{array}$ & $\mathrm{dmft}=4.5$ \\
\hline $\begin{array}{l}\text { Citrus juice- } \\
\text { frequent } \\
\text { consumption } \\
\text { (mixed } \\
\text { dentition) }\end{array}$ & + & $\begin{array}{l}\text { Abbass et } \\
\text { al. } 2019 \\
\text { (5) } \\
\text { (CS) }\end{array}$ & Egypt & $\begin{array}{l}\text { Primary. } \\
\text { Mixed, } \\
\text { Permanent }\end{array}$ & 369 & $\begin{array}{l}3-18 y \\
(M, F)\end{array}$ & Clinic & $\begin{array}{l}\text { WHO } \\
\text { (dmft, deft, } \\
\text { DMFT) }\end{array}$ & $\begin{array}{l}\text { Kruskal- } \\
\text { Wallis, } \\
\text { Spearman's }\end{array}$ & $\begin{array}{l}\text { DCP }=74 \% \\
\text { dmft=3.23 } \\
\text { (SD 4.07) } \\
\text { deft }=4.21 \\
\text { (SD 3.21) } \\
\text { DMFT }=1.04 \\
\text { (SD 1.56) }\end{array}$ \\
\hline $\begin{array}{l}\text { Fruit squash- } \\
\text { frequent } \\
\text { consumption }\end{array}$ & + & $\begin{array}{l}\text { Huew et } \\
\text { al. } 2012 \\
(6) \\
\text { (CS) }\end{array}$ & Libya & Permanent & 791 & $\begin{array}{l}12 \mathrm{y} \\
(\mathrm{M}, \mathrm{F})\end{array}$ & School & $\begin{array}{l}\text { WHO } \\
\text { (DMFT) }\end{array}$ & $\begin{array}{l}\text { Multivariate } \\
\text { stepwise } \\
\text { regression }\end{array}$ & $\begin{array}{l}\mathrm{DCP}=57.8 \% \\
\mathrm{DMFT}=1.68 \\
\mathrm{DMFS}=2.38\end{array}$ \\
\hline $\begin{array}{l}\text { Fruit squash- } \\
\text { frequent } \\
\text { consumption }\end{array}$ & + & $\begin{array}{l}\text { Sayegh et } \\
\text { al. } 2002^{\text {b }} \\
\text { (7) } \\
\text { Sayegh et } \\
\text { al. } 2005^{\text {b }} \\
\text { (8) } \\
\text { (CS) }\end{array}$ & Jordan & Primary & 1140 & $\begin{array}{l}4-5 y \\
(M, F)\end{array}$ & School & WHO (dmft) & $\begin{array}{l}\text { Multivariate } \\
\text { analysis }\end{array}$ & $\begin{array}{l}\mathrm{DCP}=67 \% \\
\mathrm{dmft}>4 \text { in } \\
31 \%\end{array}$ \\
\hline $\begin{array}{l}\text { Fruit squash- } \\
\text { frequent } \\
\text { consumption }\end{array}$ & + & $\begin{array}{l}\text { Al-Malik } \\
\text { et al. } \\
2002 \text { (4) } \\
\text { (CS) }\end{array}$ & KSA & Primary & 987 & $\begin{array}{l}2-5 y \\
(M, F)\end{array}$ & School & BASCD & $\begin{array}{l}\text { Stepwise } \\
\text { multiple } \\
\text { logistic } \\
\text { regression }\end{array}$ & $\begin{array}{l}\mathrm{DCP}=73 \% \\
\mathrm{ECCP}=43 \% \\
\mathrm{dmft}=4.8 \\
\mathrm{dmfs}=12.7\end{array}$ \\
\hline Tea with sugar & + & Sayegh et & Jordan & Primary & 1140 & $4-5 y$ & School & WHO (dmft) & Multivariate & $\mathrm{DCP}=67 \%$ \\
\hline
\end{tabular}




\begin{tabular}{|c|c|c|c|c|c|c|c|c|c|c|}
\hline & & $\begin{array}{l}\text { al. } 2002 \\
\text { (7) } \\
\text { (CS) }\end{array}$ & & & & $(\mathrm{M}, \mathrm{F})$ & & & analysis & $\begin{array}{l}\mathrm{dmft}>4 \text { in } \\
31 \%\end{array}$ \\
\hline Tea with sugar & + & $\begin{array}{l}\text { Hashim } \\
\text { et al. } \\
2009^{a} \\
\text { (3) } \\
\text { (CS) }\end{array}$ & UAE & Primary & 1036 & $\begin{array}{l}5-6 y \\
(M, F)\end{array}$ & School & $\begin{array}{l}\text { WHO } \\
\text { (dmft) }\end{array}$ & $\begin{array}{l}\text { Adjusted Risk } \\
\text { Ratio } \\
\text { Bivariate } \\
\text { analysis }\end{array}$ & $\mathrm{dmft}=4.5$ \\
\hline Flavoured milk & + & $\begin{array}{l}\text { Alhabdan } \\
\text { et al. } \\
2018 \text { (2) } \\
\text { (CS) }\end{array}$ & KSA & Primary & 578 & $\begin{array}{l}6-8 y \\
(M)\end{array}$ & School & WHO (dmft) & $\begin{array}{l}\text { Adjusted Odds } \\
\text { Ratios, } \\
\text { Multivariate } \\
\text { model logistic } \\
\text { regression }\end{array}$ & $\begin{array}{l}\mathrm{DCCP}=83 \% \\
\mathrm{dmft}=4.20 \\
(\mathrm{SD} 2.96)\end{array}$ \\
\hline $\begin{array}{l}\text { Sweetened } \\
\text { beverages }^{c}\end{array}$ & + & $\begin{array}{l}\text { Elamin et } \\
\text { al. } 2018 \\
\text { (9) } \\
\text { (CS) }\end{array}$ & UAE & Primary & 186 & $\begin{array}{l}1.5-4 y \\
(M, F)\end{array}$ & School & WHO (dmft) & $\begin{array}{l}\text { T-test, } \\
\text { Pearson's }\end{array}$ & $\begin{array}{l}\text { DCP: } 41 \% \\
\text { dmft=1.7 } \\
\text { (SD 2.81) }\end{array}$ \\
\hline $\begin{array}{l}\text { Sweetened } \\
\text { beverages }^{c}\end{array}$ & Unclear & $\begin{array}{l}\text { Khadri et } \\
\text { al. } 2018 \\
\text { (10) } \\
\text { (CS) }\end{array}$ & UAE & Permanent & 803 & $\begin{array}{l}11-17 \text { y } \\
(M, F)\end{array}$ & School & $\begin{array}{l}\text { WHO } \\
\text { (DMFT) }\end{array}$ & $\begin{array}{l}\text { Multivariate } \\
\text { regression }\end{array}$ & $\begin{array}{l}\text { DCP }=75 \% \\
\text { DMFT }=3.19 \\
(\text { SD 2.9) }\end{array}$ \\
\hline $\begin{array}{l}\text { Sweetened } \\
\text { beverages }^{c}\end{array}$ & + & $\begin{array}{l}\text { Ahmed et } \\
\text { al. } 2007 \\
(11) \\
\text { (CS) }\end{array}$ & Iraq & Permanent & 392 & $\begin{array}{l}12 y \\
(M, F)\end{array}$ & School & $\begin{array}{l}\text { WHO } \\
\text { (DMFT) }\end{array}$ & ANOVA & $\begin{array}{l}\mathrm{DCP}=62 \% \\
\mathrm{DMFT}=1.7\end{array}$ \\
\hline Sugar rich food & & & & & & & & & & \\
\hline $\begin{array}{l}\text { Sugar } \\
\text { containing } \\
\text { foods }^{d}\end{array}$ & + & $\begin{array}{l}\text { Quadri et } \\
\text { al. } 2015 \\
\text { (12) } \\
\text { (CS) }\end{array}$ & KSA & $\begin{array}{l}\text { Primary } \\
\text { Permanent }\end{array}$ & 853 & $\begin{array}{l}6-15 y \\
(M, F)\end{array}$ & School & WHO & $\begin{array}{l}\text { Multi } \\
\text { regression }\end{array}$ & $\mathrm{DCP}=91.3 \%$ \\
\hline $\begin{array}{l}\text { Sugar } \\
\text { containing } \\
\text { foods }^{d}\end{array}$ & + & $\begin{array}{l}\text { Abbass et } \\
\text { al. } 2019 \\
\text { (5) } \\
\text { (CS) }\end{array}$ & Egypt & $\begin{array}{l}\text { Primary. } \\
\text { Mixed, } \\
\text { Permanent }\end{array}$ & 369 & $\begin{array}{l}3-18 y \\
(M, F)\end{array}$ & Clinic & $\begin{array}{l}\text { WHO } \\
\text { (dmft, deft, } \\
\text { DMFT) }\end{array}$ & $\begin{array}{l}\text { Kruskal- } \\
\text { Wallis, } \\
\text { Spearman's }\end{array}$ & $\begin{array}{l}\text { DCP }=74 \% \\
\text { dmft }=3.23 \\
\text { (SD 4.07) } \\
\text { deft }=4.21 \\
\text { (SD 3.21) } \\
\text { DMFT }=1.04 \\
\text { (SD 1.56) }\end{array}$ \\
\hline $\begin{array}{l}\text { Sugar } \\
\text { containing } \\
\text { foods }^{d}\end{array}$ & + & $\begin{array}{l}\text { Jaghasi } \\
\text { et al. } \\
2012 \text { (13) } \\
\text { (CS) }\end{array}$ & Syria & $\begin{array}{l}\text { Not } \\
\text { specified }\end{array}$ & 504 & $\begin{array}{l}6-12 y \\
(M, F)\end{array}$ & School & WHO & $\begin{array}{l}\text { Logistic } \\
\text { regression }\end{array}$ & $\mathrm{DCP}=85 \%$ \\
\hline $\begin{array}{l}\text { Sugar } \\
\text { containing } \\
\text { foods }^{d}\end{array}$ & + & $\begin{array}{l}\text { Hashim } \\
\text { et al. } \\
2009^{\mathrm{a}}(3) \\
\text { (CS) }\end{array}$ & UAE & Primary & 1036 & $\begin{array}{l}5-6 y \\
(M, F)\end{array}$ & School & $\begin{array}{l}\text { WHO } \\
\text { (dmft) }\end{array}$ & $\begin{array}{l}\text { Adjusted Risk } \\
\text { Ratio, } \\
\text { Bivariate } \\
\text { analysis }\end{array}$ & $\mathrm{dmft}=4.5$ \\
\hline $\begin{array}{l}\text { Sugar } \\
\text { containing } \\
\text { foods }^{\mathrm{d}} \text { - } \\
\text { frequent } \\
\text { consumption }\end{array}$ & + & $\begin{array}{l}\text { Elamin et } \\
\text { al. } 2018 \\
\text { (9) } \\
\text { (CS) }\end{array}$ & UAE & Primary & 186 & $\begin{array}{l}1.5-4 y \\
(M, F)\end{array}$ & School & WHO (dmft) & $\begin{array}{l}\text { T-test, } \\
\text { Pearson's }\end{array}$ & $\begin{array}{l}\text { DCP: } 41 \% \\
\text { dmft=1.7 } \\
(\text { SD 2.81) }\end{array}$ \\
\hline $\begin{array}{l}\text { Sugar } \\
\text { containing } \\
\text { foods }^{\mathrm{d}} \text { - } \\
\text { frequent } \\
\text { consumption }\end{array}$ & + & $\begin{array}{l}\text { Sayegh et } \\
\text { al. } 2002^{b} \\
\text { (7) } \\
\text { Sayegh et } \\
\text { al. } 2005^{b}\end{array}$ & Jordan & Primary & 1140 & $\begin{array}{l}4-5 y \\
(M, F)\end{array}$ & School & WHO (dmft) & $\begin{array}{l}\text { Multivariate } \\
\text { analysis }\end{array}$ & $\begin{array}{l}\mathrm{DCP}=67 \% \\
\mathrm{dmft}>4 \text { in } \\
31 \%\end{array}$ \\
\hline
\end{tabular}


(8)(CS)

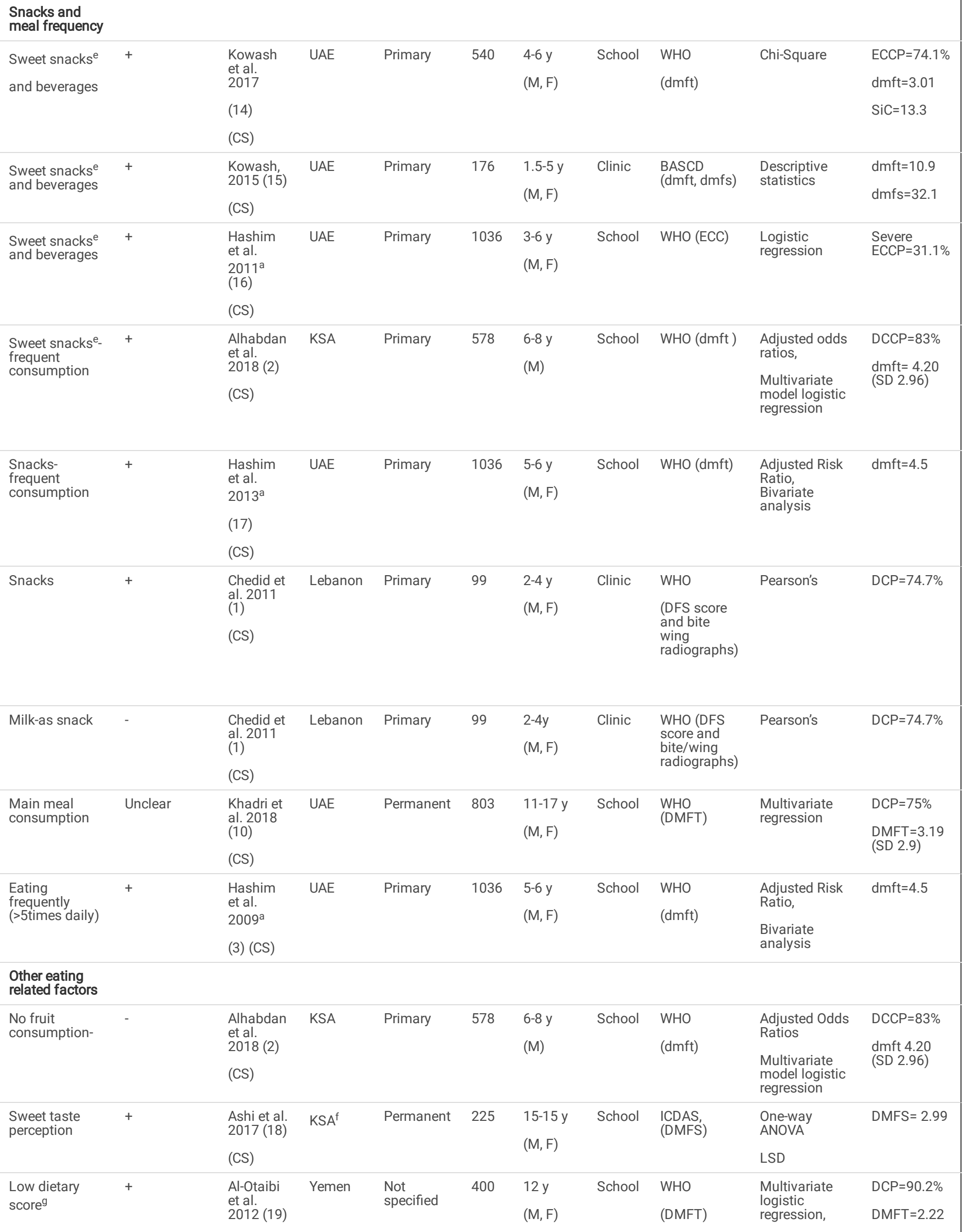


(CS)

\begin{tabular}{|c|c|c|c|c|c|c|c|c|c|c|}
\hline \multirow[t]{2}{*}{$\begin{array}{l}\text { Low nutrient } \\
\text { food }^{\text {h-frequent }} \\
\text { consumption }\end{array}$} & \multirow[t]{2}{*}{+} & $\begin{array}{l}\text { İnan- } \\
\text { Eroğlu et } \\
\text { al. } 2017 \\
(20)\end{array}$ & Turkey & Primary & 395 & $\begin{array}{l}36-71 \mathrm{~m} \\
(\mathrm{M}, \mathrm{F})\end{array}$ & School & $\begin{array}{l}\text { WHO } \\
\text { (dmft, dmfs) }\end{array}$ & $\begin{array}{l}\text { Mann-Whitney, } \\
\text { Kruskal-Wallis }\end{array}$ & $\begin{array}{l}\mathrm{dmft}=4.7 \\
\mathrm{dmfs}=8.0\end{array}$ \\
\hline & & (CS) & & & & & & & & \\
\hline
\end{tabular}

\begin{tabular}{|c|c|c|c|c|c|c|c|c|c|c|}
\hline $\begin{array}{l}\text { Dairy products- } \\
\text { low } \\
\text { consumption }\end{array}$ & + & $\begin{array}{l}\text { Jaghasi } \\
\text { et al. } \\
2012 \text { (13) }\end{array}$ & Syria & $\begin{array}{l}\text { Not } \\
\text { specified }\end{array}$ & 504 & $\begin{array}{l}6-12 y \\
(M, F)\end{array}$ & School & WHO & $\begin{array}{l}\text { Logistic } \\
\text { regression }\end{array}$ & $\mathrm{DCP}=85 \%$ \\
\hline
\end{tabular}

(CS)

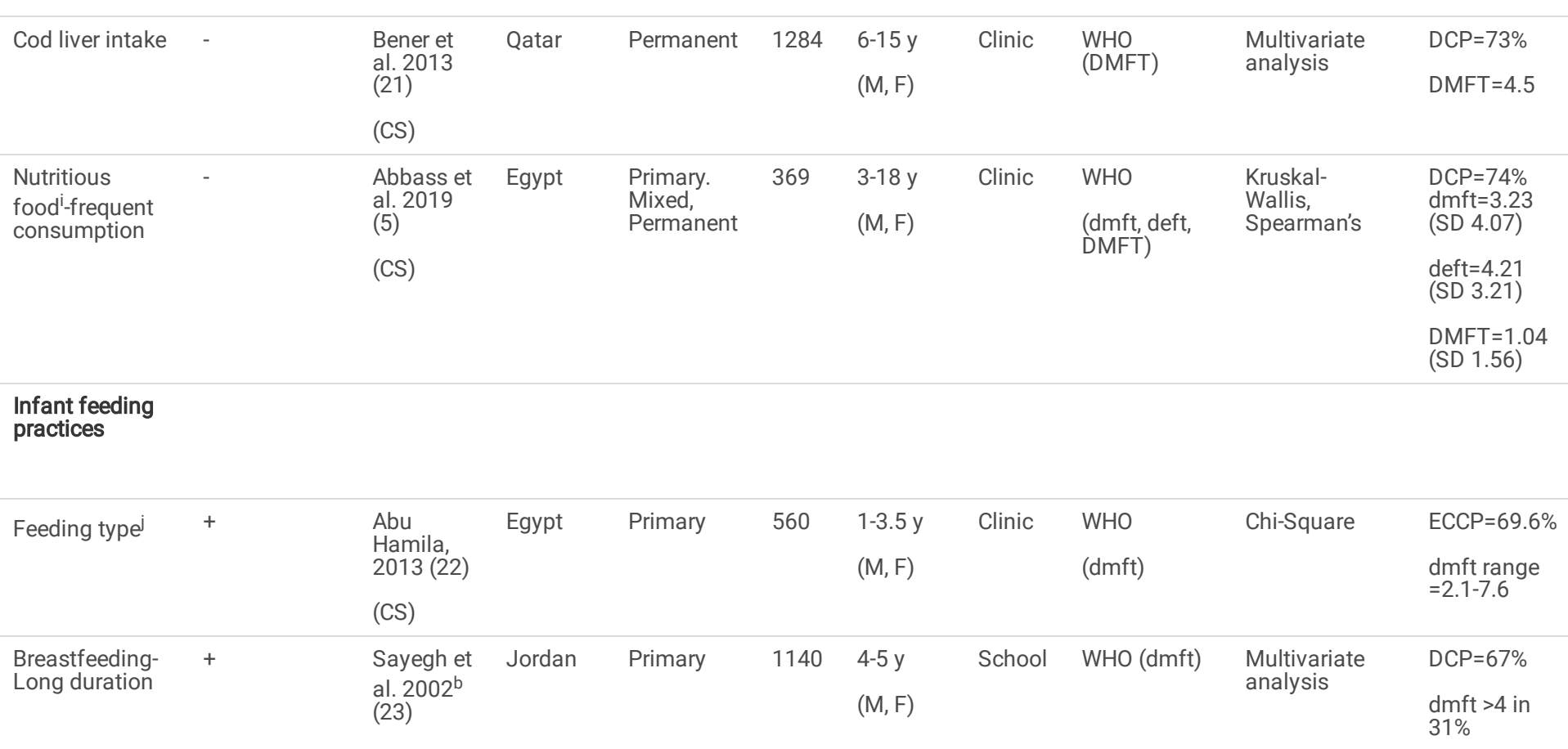

\begin{tabular}{|c|c|c|c|c|c|c|c|c|c|c|}
\hline & & $\begin{array}{l}\text { Sayegh et } \\
\text { al. } 2005^{\mathrm{b}} \\
\text { (8) (CS) }\end{array}$ & & & & & & & & \\
\hline $\begin{array}{l}\text { Breastfeeding } \\
\text {-On demand } \\
\text { feeding }\end{array}$ & + & $\begin{array}{l}\text { Sayegh et } \\
\text { al. } 2002^{\text {b }} \\
(23)\end{array}$ & Jordan & Primary & 1140 & $\begin{array}{l}4-5 y \\
(M, F)\end{array}$ & School & WHO (dmft) & $\begin{array}{l}\text { Multivariate } \\
\text { analysis }\end{array}$ & $\begin{array}{l}\mathrm{DCP}=67 \% \\
\mathrm{dmft}>4 \text { in } \\
31 \%\end{array}$ \\
\hline
\end{tabular}

\begin{tabular}{|c|c|c|c|c|c|c|c|c|c|c|}
\hline & & $\begin{array}{l}\text { Sayegh et } \\
\text { al. } 2005^{\text {b }} \\
\text { (CS) } \\
\text { (8) }\end{array}$ & & & & & & & & \\
\hline $\begin{array}{l}\text { Formula } \\
\text { feeding }\end{array}$ & + & $\begin{array}{l}\text { Alhabdan } \\
\text { et al. } \\
2018 \text { (2) } \\
\text { (CS) }\end{array}$ & KSA & Primary & 578 & $\begin{array}{l}6-8 y \\
(M)\end{array}$ & School & WHO (dmft) & $\begin{array}{l}\text { Adjusted Odds } \\
\text { Ratios, } \\
\text { Multivariate } \\
\text { model logistic } \\
\text { regression }\end{array}$ & $\begin{array}{l}\mathrm{DCCP}=83 \% \\
\mathrm{dmft}=4.20 \\
(\mathrm{SD} 2.96)\end{array}$ \\
\hline $\begin{array}{l}\text { Formula } \\
\text { feeding }\end{array}$ & + & $\begin{array}{l}\text { Bener et } \\
\text { al. } 2013 \\
(21) \\
\text { (CS) }\end{array}$ & Qatar & Permanent & 1284 & $\begin{array}{l}6-15 y \\
(M, F)\end{array}$ & Clinic & $\begin{array}{l}\text { WHO } \\
\text { (DMFT) }\end{array}$ & $\begin{array}{l}\text { Multivariate } \\
\text { analysis }\end{array}$ & $\begin{array}{l}\mathrm{DCP}=73 \% \\
\mathrm{DMFT}=4.5\end{array}$ \\
\hline
\end{tabular}




\begin{tabular}{|c|c|c|c|c|c|c|c|c|c|c|}
\hline $\begin{array}{l}\text { Formula } \\
\text { feeding }\end{array}$ & + & $\begin{array}{l}\text { Qadri et } \\
\text { al. } 2012 \\
(24) \\
\text { (CS) }\end{array}$ & Syria & Primary & 400 & $\begin{array}{l}3-5 y \\
(M, F)\end{array}$ & School & $\begin{array}{l}\text { ECC } \\
\text { WHO (dmft, } \\
\text { dmfs) }\end{array}$ & $\begin{array}{l}\text { Logistic } \\
\text { regression }\end{array}$ & $\begin{array}{l}\mathrm{ECCP}=48 \% \\
\mathrm{DCP}=70 \% \\
\mathrm{dmft}=4.25 \\
(\mathrm{SD} 4.24)\end{array}$ \\
\hline $\begin{array}{l}\text { Night feeding - } \\
\text { bottle }\end{array}$ & + & $\begin{array}{l}\text { Mohebbi, } \\
2008(25) \\
(\mathrm{CS})\end{array}$ & Iran & Primary & 504 & $\begin{array}{l}1-3 y \\
(M, F)\end{array}$ & Clinic & WHO & $\begin{array}{l}\text { T-test, } \\
\text { Chi-Square, } \\
\text { ANOVA, } \\
\text { Logistic } \\
\text { regression }\end{array}$ & $\begin{array}{l}\text { DCP }=3-26 \% \\
\text { depending } \\
\text { on age }\end{array}$ \\
\hline $\begin{array}{l}\text { Night feeding - } \\
\text { bottle }\end{array}$ & + & $\begin{array}{l}\text { Ozer et al. } \\
2011 \text { (26) } \\
\text { (CS) }\end{array}$ & Turkey & Primary & 226 & $\begin{array}{l}3-6 y \\
(M, F)\end{array}$ & School & $\begin{array}{l}\text { WHO (dmft) } \\
\text { AAPD } \\
\text { (ECC) }\end{array}$ & $\begin{array}{l}\text { Bivariate } \\
\text { analysis }\end{array}$ & $\begin{array}{l}\mathrm{ECCP}=46.9 \% \\
\mathrm{dmft}=2.87\end{array}$ \\
\hline Night feeding & + & $\begin{array}{l}\text { Kabil \& } \\
\text { Eltawil, } \\
2016 \\
(27) \\
(\mathrm{CS})\end{array}$ & Egypt & Primary & 140 & $\begin{array}{l}2-4 y \\
(M, F)\end{array}$ & Clinic & $\begin{array}{l}\text { WHO } \\
\text { (DMFT) }\end{array}$ & $\begin{array}{l}\text { Logistic } \\
\text { regression }\end{array}$ & $\mathrm{DMFT}=9.96$ \\
\hline Night feeding & + & $\begin{array}{l}\text { Kabil \& } \\
\text { Eltawil, } \\
2017 \text { (28) } \\
\text { (CS) }\end{array}$ & Egypt & Primary & 108 & $\begin{array}{l}2-4 y \\
(M, F)\end{array}$ & Clinic & $\begin{array}{l}\text { WHO } \\
\text { (ECC) }\end{array}$ & $\begin{array}{l}\text { Logistic } \\
\text { regression }\end{array}$ & $\begin{array}{l}\text { ECCP=57\% } \\
\text { (2-3yrs), } \\
73 \% \text { (3-4yrs) }\end{array}$ \\
\hline $\begin{array}{l}\text { Bottle feeding- } \\
\text { on } \\
\text { demand }\end{array}$ & + & $\begin{array}{l}\text { Sayegh et } \\
\text { al. } 2002^{b} \\
(23) \\
\text { Sayegh et } \\
\text { al. } 2005^{b} \\
(8)(C S)\end{array}$ & Jordan & Primary & 1140 & $\begin{array}{l}4-5 y \\
(M, F)\end{array}$ & School & WHO (dmft) & $\begin{array}{l}\text { Multivariate } \\
\text { analysis }\end{array}$ & $\begin{array}{l}\mathrm{DCP}=67 \% \\
\mathrm{dmft}>4 \text { in } \\
31 \%\end{array}$ \\
\hline $\begin{array}{l}\text { Sleep with } \\
\text { bottle }\end{array}$ & + & $\begin{array}{l}\text { Alhabdan } \\
\text { et al. } \\
2018 \text { (2) } \\
\text { (CS) }\end{array}$ & KSA & Primary & 578 & $\begin{array}{l}6-8 y \\
(M)\end{array}$ & School & WHO (dmft) & $\begin{array}{l}\text { Adjusted Odds } \\
\text { Ratios, } \\
\text { Multivariate } \\
\text { model logistic } \\
\text { regression }\end{array}$ & $\begin{array}{l}\text { DCCP }=83 \% \\
\mathrm{dmft}=4.20 \\
(\mathrm{SD} 2.96)\end{array}$ \\
\hline $\begin{array}{l}\text { Sleep next to } \\
\text { mother }\end{array}$ & + & $\begin{array}{l}\text { Sayegh et } \\
\text { al. } 2002^{\mathrm{b}} \\
(23) \\
\text { Sayegh et } \\
\text { al. 2005 } \\
(8) \\
\text { (CS) }\end{array}$ & Jordan & Primary & 1140 & $\begin{array}{l}4-5 y \\
(M, F)\end{array}$ & School & WHO (dmft) & $\begin{array}{l}\text { Multivariate } \\
\text { analysis }\end{array}$ & $\begin{array}{l}\mathrm{DCP}=67 \% \\
\mathrm{dmft}>4 \text { in } \\
31 \%\end{array}$ \\
\hline Dummy use & + & $\begin{array}{l}\text { Sayegh et } \\
\text { al. } 2002^{b} \\
(23) \\
\text { Sayegh et } \\
\text { al. } 2005^{b} \\
\text { (8) } \\
\text { (CS) }\end{array}$ & Jordan & Primary & 1140 & $\begin{array}{l}4-5 y \\
(M, F)\end{array}$ & School & WHO (dmft) & $\begin{array}{l}\text { Multivariate } \\
\text { analysis }\end{array}$ & $\begin{array}{l}\mathrm{DCP}=67 \% \\
\mathrm{dmft}>4 \text { in } \\
31 \%\end{array}$ \\
\hline $\begin{array}{l}\text { Dummy- } \\
\text { sweetened }\end{array}$ & + & $\begin{array}{l}\text { Al-Malik } \\
\text { et al. }\end{array}$ & KSA & Primary & 987 & $2-5 y$ & School & $\begin{array}{l}\text { BASCD } \\
\text { (dmft, }\end{array}$ & $\begin{array}{l}\text { Logistic } \\
\text { regression }\end{array}$ & $\mathrm{DCP}=73 \%$ \\
\hline
\end{tabular}




\begin{tabular}{|c|c|c|c|c|c|c|c|c|c|c|}
\hline \multirow[t]{2}{*}{$\begin{array}{l}\text { Shared spoons } \\
\text { between } \\
\text { mother and } \\
\text { childk }\end{array}$} & \multirow[t]{2}{*}{+} & $\begin{array}{l}\text { Cogulu et } \\
\text { al. } 2008 \\
(29)\end{array}$ & Turkey & Primary & 92 & \multirow[t]{2}{*}{$\begin{array}{l}15-35 \mathrm{~m} \\
(\mathrm{M}, \mathrm{F})\end{array}$} & \multirow[t]{2}{*}{ Clinic } & \multirow[t]{2}{*}{$\begin{array}{l}\text { WHO } \\
\text { (dft, dfs) }\end{array}$} & \multirow[t]{2}{*}{$\begin{array}{l}\text { Logistic } \\
\text { regression }\end{array}$} & $\begin{array}{l}\text { Final } \\
\text { DCP }=45 \% \\
\text { Final } d f t=1.0\end{array}$ \\
\hline & & $\begin{array}{l}\text { (L-24 } \\
\text { months) }\end{array}$ & & & & & & & & $\begin{array}{l}\text { Final } \\
\mathrm{dfs}=1.8\end{array}$ \\
\hline
\end{tabular}

AAPD American Association Paediatric Dentistry, BASCD British Association for the Study of Community Dentistry, CS Cross-sectional, CC Case control, DCP Dental caries prevalence, deft decayed, extracted due to caries and filled primary teeth, $d f s$ decayed, filled surfaces in primary teeth, $d f t$ decayed, filled primary teeth, $d m f s$ decayed, missing and filled surfaces in primary teeth; DMFS decayed, missing and filled surfaces in permanent teeth, $d m f t$ decayed, missing, filled primary teeth, DMFT decayed, missing, filled permanent teeth, ECC Early childhood caries, ECCP Early childhood caries prevalence, $F$ Female, ICADS The international caries Detection and Assessment System, $L$ Longitudinal, KSA Kingdom of Saudi Arabia, $m$ months $M$ Male, WHO World Health Organisation, SiC Significant caries index, SD Standard deviation, $y$ years

${ }^{a}$ Hashim et al. 2006, Hashim et al. 2009, Hashim et al. 2011 and Hashim et al. 2013 seem to be based on the same study population but reporting different results.

bSayegh et al. 2002 and Sayegh et al. 2005 seem to be based on the same study population and the results mentioned in this table, have been reported in both articles.

'Sweetend beverages refer to the consumption of various sweet beverages like soft drinks, fruit squashes, tea with sugar, flavoured milk, etc.

${ }^{\mathrm{d}}$ Sugar rich food may include consumption of all/and mix of items like candy, chocolates, dates, ice-cream, cakes, muffins, etc.

eSweet snacks include various food items with high sugar content.

${ }^{f}$ KSA was part of this multinational study which also included Italy and Mexico. Only the results for KSA are presented in this table.

9The dietary score was based on a few questions related to the consumption of cariogenic food and eating patterns with yes/no answer options.

${ }^{\text {h}}$ Assessed by the Healthy Eating Index (HEI) 2010 and the Mediterranean Diet Quality Index for children and adolescents (KIDMED).

'Nutritious food refers to a frequent consumption of high nutrient food like fruits, vegetables, beans, milk, eggs etc.

iThe feeding type had an impact on the caries prevalence as follows: $75.39 \%$ of breastfeed children, $70.39 \%$ of the formula fed, $68.67 \%$ of those who were weaned and $55 \%$ of those who got a mix of breast milk and formula had dental caries respectively.

kDuring the baseline sampling mothers reported that they put their child's spoon into their own mouth while feeding their child.

\section{Figures}




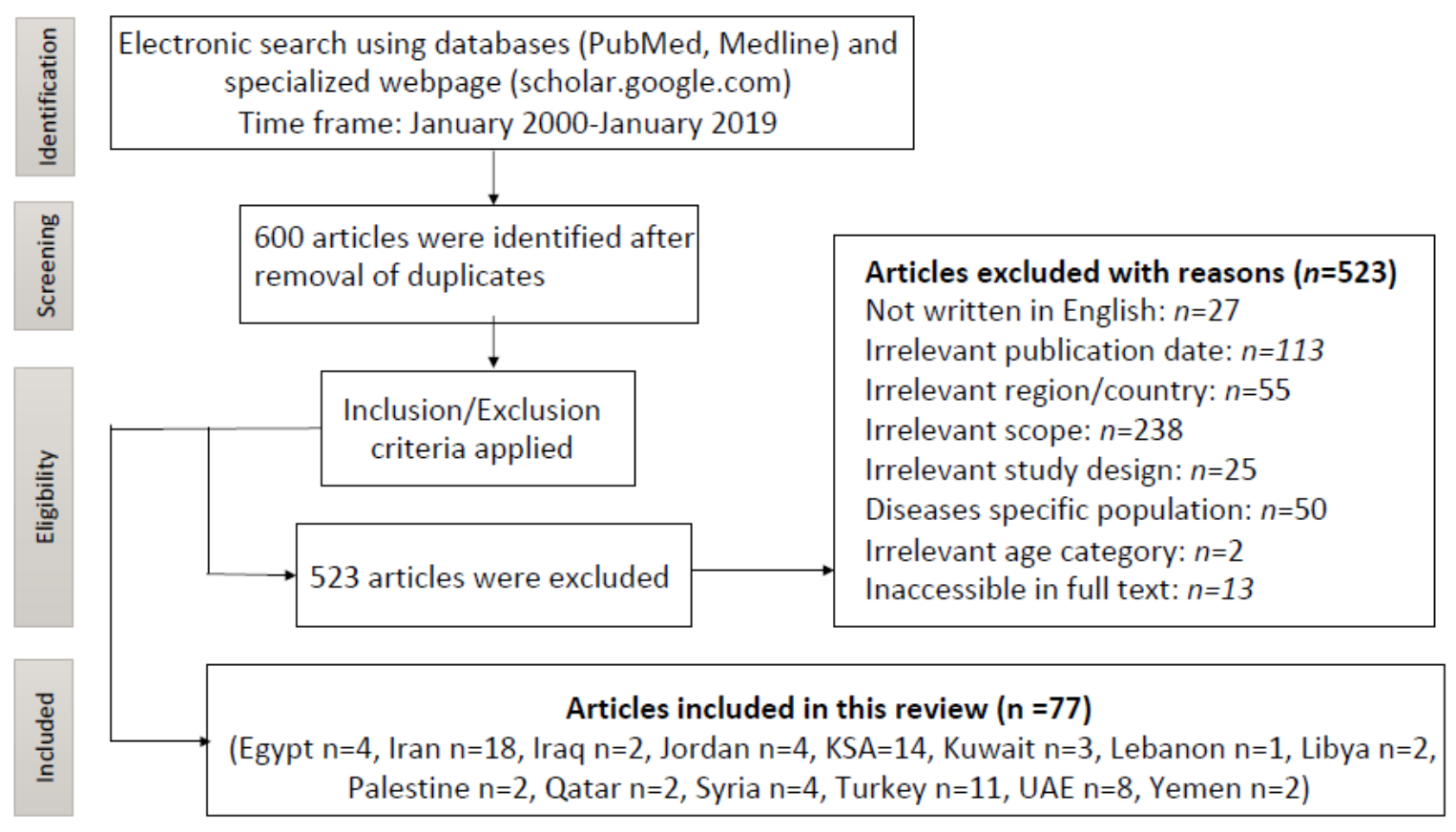

Figure 1

Flow chart of the literature search

\section{Supplementary Files}

This is a list of supplementary files associated with this preprint. Click to download.

- PRISMA2009checklistOHEAD2001197.doc 